\title{
Metal Complexes, an Untapped Source of Antibiotic Potential?
}

\author{
Angelo Frei \\ Centre for Superbug Solutions, Institute for Molecular Bioscience, The University of Queensland, St Lucia 4072, \\ Australia; angelo.frei.ch@gmail.com
}

Received: 3 January 2020; Accepted: 12 February 2020; Published: 18 February 2020

\begin{abstract}
With the widespread rise of antimicrobial resistance, most traditional sources for new drug compounds have been explored intensively for new classes of antibiotics. Meanwhile, metal complexes have long had only a niche presence in the medicinal chemistry landscape, despite some compounds, such as the anticancer drug cisplatin, having had a profound impact and still being used extensively in cancer treatments today. Indeed, metal complexes have been largely ignored for antibiotic development. This is surprising as metal compounds have access to unique modes of action and exist in a wider range of three-dimensional geometries than purely organic compounds. These properties make them interesting starting points for the development of new drugs. In this perspective article, the encouraging work that has been done on antimicrobial metal complexes, mainly over the last decade, is highlighted. Promising metal complexes, their activity profiles, and possible modes of action are discussed and issues that remain to be addressed are emphasized.
\end{abstract}

Keywords: antibiotics; antimicrobials; metal complexes; metal-based drugs; medicinal chemistry

\section{Introduction}

At first sight it might seem that the antibiotic drug pipeline is slowly recovering after several decades of extreme drought. However, a closer look at the 42 compounds currently in clinical development highlights a major problem in the field. Only 11 of these compounds represent entirely new structural classes, while the rest are merely derivatives and modifications of already approved antibiotics [1]. While these derivatives represent a viable short-term solution, it is likely that bacteria will quickly develop resistance to these compounds as well. Another feature shared by all these molecules and most lead compounds in both preclinical and clinical development is that they are purely organic compounds. This observation can be rationalized by the fact that most of the chemistry we find in living organisms, from DNA to proteins and metabolites, is mostly based around carbon and a few other elements. At the same time, transition metals are generally thought to be toxic and only to be useful as catalysts or as materials in alloys, coatings, and electronic devices, etc. On the other hand, metals, while present in much smaller quantities, are just as essential for life. Without metals most enzymes would not be able to conduct their impressively fine-tuned transformations [2]. Metal compounds have access to modes of action that are difficult or even impossible to achieve with organic molecules alone. Furthermore, coordination compounds of metals have access to a vast variety of different geometries and generally possess a higher 3D character compared to the generally rather flat organic molecules. The three-dimensionality of molecules has repeatedly been associated with higher clinical success rates [3,4]. This is because the shape of a molecule is one of the crucial factors in determining its biological fate and activity [5-7]. Very recently, Morrison et al., reported a thorough analysis of the potential of metal complexes as 'metallofragments' for drug discovery. The authors found that metallofragments enable access to structural 3D space that is not covered by the vast majority of organic compounds [8]. 
Metal-containing compounds have played a small but seminal role in medicinal chemistry of throughout the 20th century. An arsenic-containing compound, Salvarsan, was discovered at the beginning of the century and became the first effective treatment of syphilis [9]. It was however the discovery of the anticancer drug cisplatin and its successors that really kickstarted the field of inorganic medicinal chemistry. Even today, platinum-based chemotherapeutics are still used in the majority of cancer treatments [10]. The gold-containing auranofin is an approved drug for the treatment of rheumatoid arthritis and is currently under investigation for its anticancer as well as antimicrobial properties [11-16]. Invigorated by these breakthrough successes, the field has expanded to many other elements in the last few decades, with complexes of titanium, iron, ruthenium, gallium, palladium, silver, gold, bismuth, and copper entering clinical trials [17-22]. The medicinal applications of these metal complexes range from anticancer to antimalaria over to neurodegenerative diseases. Strangely, antibacterial applications are remarkably sparse in this list and the number of literature reports on metal-based antimicrobials is dwarfed by the much more frequent publications on metal-based anticancer compounds. This is surprising as metals such as bismuth and silver have long been known to possess antibacterial properties. Some medicinal products are currently available. There are however a variety of products, such as silver-coated underwear, with a more dubious scientific basis. Nevertheless, the systematic evaluation of the antimicrobial properties of metal complexes has increased in pace over the last decade, with several reports highlighting the activity and potential modes of action of metal-based antibiotics. This perspective article will discuss the major discoveries in the non-traditional field of metal complex-based antibiotic compounds, focusing on the last decade and the most promising elements, with coverage of molecular metal-compounds but not supramolecular assemblies or nanoparticles which have been reviewed extensively elsewhere [23-26]. In general, the article will restrict itself to studies into metal complexes, i.e., compounds where the metal ion is more or less stably coordinated by one or multiple ligands. A recent review provides an overview of organometallic derivatives of known antibacterial drugs [27]. While some overlaps exist, this work focuses on all metal-containing small molecules and includes many important reports that were published in 2019. In conclusion, the advantages and disadvantages of metal-based drugs will be discussed and future promising directions for the development of the field in the coming years will be highlighted.

\section{Silver}

One of the first documented medicinal applications of silver was reported in 980 A. D. when Avicenna described the use of silver filings as a blood purifier for offensive breath and heart-palpitations [28]. In the 18th and 19th century, silver compounds found a range of applications such as the use of colloidal silver for wound antisepsis and silver nitrate for the treatment of burn wounds [29]. Even though the discovery of antibiotics diminished the use of silver, a range of silver-based compounds are still employed today for their medicinal properties [30]. Almost 300 clinical trials featuring silver-containing compounds and formulations for a range of different applications are currently ongoing or in the recruitment phase [17]. Silver sulfadiazine is approved by the Food and Drug Administration (FDA) in the US for its use as a broad spectrum topical antibiotic for some burn wounds $[27,31]$. However, some trials have suggested that silver-based medicines generally do not perform better than non-silver-based treatments. A 2017 report on a randomized control trial comparing polyhexanide/betaine gel with silver sulfadiazine in 46 adult patients with partial-thickness burns found no significant differences in healing times, infection rates, and treatment costs in both groups. However, the pain score of the polyhexanide/betaine gel group was shown to be lower than in the silver sulfadiazine group [32]. In a two-arm open label multicenter randomized controlled trial in 2019, 89 adult patients with acute partial thickness burns were treated either with Flaminal ${ }^{\mathbb{R}}$ Forte (hydrated alginate polymers with a biologic enzyme system based on glucose oxidase and lactoperoxidase stabilized by guaiacol) or Flamazine ${ }^{\circledR}$ (silver sulfadiazine). No significant difference was found in the average wound-healing time, but Flaminal ${ }^{\circledR}$ Forte was deemed advantageous due to 
less frequently required dressing changes [33]. Finally, a 2019 meta-analysis of 81 studies found that $11 / 11$ studies that met the inclusion criteria of the review found silver sulfadiazine to be inferior to alternative treatments in the mean wound-healing time [34].

In the last 20 years, some new classes of silver complexes have garnered attention for their antibacterial properties, in particular $\mathrm{N}$-heterocyclic carbene (NHC) complexes of silver(I). A comprehensive summary of antimicrobial silver compounds can be found in several recent reviews [27,35-37]. While some complexes from the late 1990s and early 2000s showed promising activity against a range of bacterial strains, no significant developments have been reported in the last years, possibly due to the fact that the exact mode of action of silver compounds remained largely unknown. It was suspected that the observed antibacterial effect is caused by the $\mathrm{Ag}(\mathrm{I})$ ions being released through dissociative mechanisms after entering the bacteria as coordination complexes. In 2019 the group of Sun published several ground-breaking studies on the molecular bacterial targets of a series of metals, including silver. By integrating gel electrophoresis with inductively coupled plasma mass spectrometry (GE-ICP-MS), the group identified 34 unique proteins targeted by silver ions (originating from $\mathrm{AgNO}_{3}$ ) in Escherichia coli, many of which play a role in glycolysis and the tricarboxylic acid (TCA) cycle [38]. Amongst these proteins, glyceraldehyde-3-phosphate dehydrogenase (GAPDH) was studied in-depth due to its importance in glycolysis. Extensive biochemical analysis combined with X-ray crystal structures of $\mathrm{Ag}(\mathrm{I})$ ions coordinated to an active site cysteine demonstrated the inhibitory role of silver ions, leading to the first identification of a bona fide molecular target of silver in bacteria. Since GAPDH binding sites are conserved among humans and bacteria, delivery systems will have to be tailored towards the latter for silver ions to be further developed as antibiotics [39]. As many of the identified targets are part of the Krebs cycle, the team hypothesized and demonstrated that supplementing the silver nitrate treatment of $E$. coli with metabolites involved in the early stages of the Krebs cycle significantly increased the antimicrobial effect of the silver compound. In most studied silver complexes, the observed antibacterial activity is ascribed to silver ions being released inside of the bacteria, suggesting that the targets identified by the group of Sun are likely also valid for metal complexes and not just silver salts such as $\mathrm{AgNO}_{3}$ [27,35-37]. Future work on silver complexes will have to focus on improving selective uptake and accumulation of silver through rational ligand design.

The studies by the group of Sun exemplify the type of work that needs to be done for metal-based compounds to be considered seriously as potential antibiotics. More work in this vein will hopefully follow in the future.

\section{Gold}

Similarly to silver, gold has garnered attention for its medicinal properties early on. Robert Koch described the activity of potassium dicyanidoaurate $(\mathrm{I})\left(\mathrm{K}\left[\mathrm{Au}(\mathrm{CN})_{2}\right]\right)$ against Mycobacterium tuberculosis in 1890 [40]. The antimicrobial properties of gold complexes have been summarized in recent review articles [41-43]. NHC complexes of gold in particular seem to possess promising antibacterial activity. However, there is a general lack of more in-depth studies beyond simple minimum inhibitory concentration (MIC) measurements in this area. In most cases where more experiments where conducted, these compounds were found to possess significant cytotoxicity against eukaryotic cells, suggesting a nonspecific mode of action rendering them unsuitable for antibacterial applications. One notable exception to this trend is auranofin (Figure 1). Auranofin is a gold-based FDA-approved antirheumatic drug. It is also currently in clinical trials for its potential anticancer applications [17]. Recently it was found to also be effective against a series of clinically relevant drug-resistant Gram positive $($ Gram $(+))$ species (Staphylococcus aureus, methicillin-resistant S. aureus (MRSA), Enterococcus faecium, and Enterococcus faecalis), as well as M. tuberculosis [15]. In contrast, almost no activity was found against Gram negative (Gram(-)) species (MIC $\geq 16 \mu \mathrm{g} / \mathrm{mL}$ against Acinobacter baumannii, Pseudomonas aeruginosa, and Klebsiella pneumoniae). A known cellular target of auranofin is thioredoxin reductase (Trx), an essential source of reducing equivalents in Gram $(+)$ bacteria and M. tuberculosis. It is proposed that the glutathione system present in Gram(-) bacteria can compensate for the loss 
of the reducing ability of Trx. Indeed, assays using a glutathione knockout $(\Delta g \operatorname{sh} A)$ mutant strain of $E$. coli resulted in higher auranofin activity. A combination of auranofin with paraquat (which generates reactive oxygen species, ROS) against $S$. aureus showed significant synergetic activity ( $\sim$-log decrease in colony forming units, $\mathrm{CFU}$ ) whereas paraquat alone had only minor antimicrobial activity $(<1 \log$ decrease in CFU). In this case it seems that the combination of increased ROS and compromised cellular defenses against oxidative stress resulted in increased bacterial death [15]. Other studies hypothesized that the outer membranes of Gram(-) species are able to prevent auranofin accumulation. This is supported by the finding that co-administration of auranofin with membrane permeabilizing antibiotics such as polymyxin B lead to restored activity against Gram(-) bacteria [44,45].

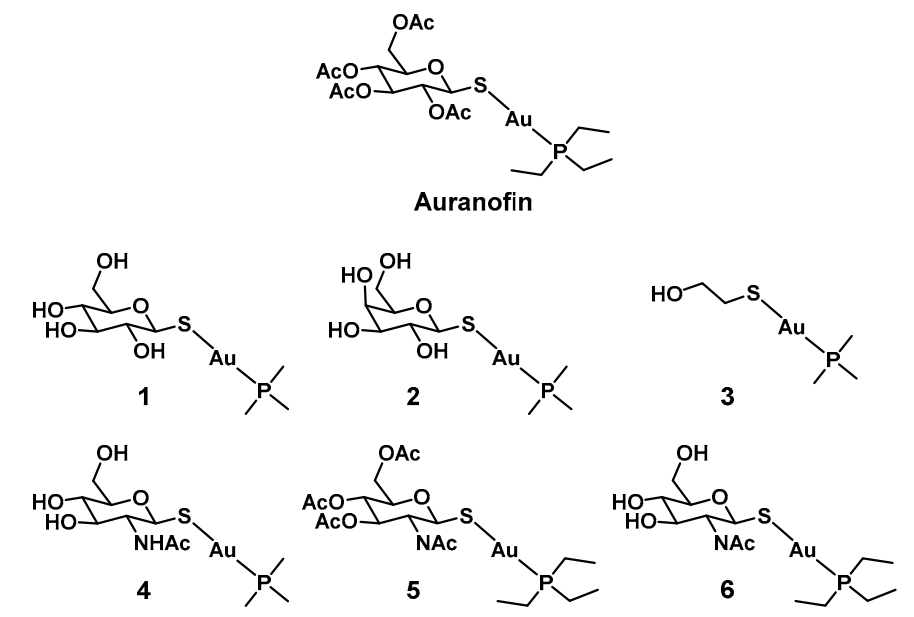

Figure 1. Structures of auranofin and its derivatives.

It was further shown that auranofin was effective at treating MRSA in a murine systemic infection model. The animals were given a single i.p. injection at either $0.12 \mathrm{or} 0.012 \mathrm{mg} / \mathrm{kg}$ once a day (the maximum tolerated dose in mice was $70 \mathrm{mg} / \mathrm{kg}$ ). Four out of eight and three out of eight mice of the respective doses survived to day 7 , whereas none of the animals in the vehicle control group survived beyond day 4. Although auranofin displays a low therapeutic index toward eukaryotic cells in vitro, chronic auranofin exposure was found to be safe for patients while taken over extended periods of time, with no cumulative toxicity observed over 5 years [46]. More recent work by Tharmalingam et al., found that no resistance could be detected in a S. aureus strain after 25 days of auranofin exposure [47]. Another report by the group of $\mathrm{Wu}$ describes potent activity of auranofin against biofilms of $S$. aureus and E. faecalis as well a synergistic microbicidal effect with linezolid, fosfomycin, and chloramphenicol in vitro and in vivo [48]. Auranofin has the added advantage of being already approved by the FDA, which could accelerate the expansion of its use to bacterial infections [15]. From these initial promising results, some groups have embarked on a quest to improve the properties of auranofin, with emphasis on reducing mammalian cytotoxicity. The group of Yan prepared 40 auranofin analogues to determine their $\operatorname{Gram}(+), \operatorname{Gram}(-)$, and cytotoxic activity, establishing a structure-activity relationship. Compounds (1-4) possessed a broader activity spectrum, with bactericidal activity against $S$. aureus, A. baumannii, Enterobacter cloacae, E faecium, and E. coli, with associated half maximal inhibitory concentration $\left(\mathrm{IC}_{50}\right)$ values between 50 and $100 \mu \mathrm{M}$ against A549 cells (Table 1) [16]. For the Gram(+) bacteria tested, the cytotoxicity was around two orders of magnitude lower than the antibacterial activity, indicating a favorable therapeutic index. The activity could be improved against Gram(-) species, however, the therapeutic index was significantly smaller. Some of the compounds in this report (4-6) were further shown to be effective inhibitors of the gastric pathogen Helicobacter pylori in a concurrent publication [49]. Overall, these findings suggest that the properties of auranofin can be optimized further for antibacterial applications. While gold is a rather 
expensive metal, the fact that auranofin is already FDA-approved could significantly facilitate the road to approval for gold-based antibiotic compounds.

Table 1. Minimum inhibitory concentration (MIC) values for auranofin analogues against a series of $\operatorname{Gram}(+)$ and Gram(-) strains (in $\mu \mathrm{M})$.

\begin{tabular}{ccccccccc}
\hline & $\boldsymbol{A} \boldsymbol{b}^{\mathbf{a}}$ & $\boldsymbol{P a} \boldsymbol{a}^{\mathbf{b}}$ & $\boldsymbol{E} \boldsymbol{c}^{\mathbf{c}}$ & $\boldsymbol{K} \boldsymbol{p}^{\mathbf{d}}$ & $\boldsymbol{S a} \boldsymbol{a}^{\mathbf{e}}$ & $\boldsymbol{E} f^{\mathbf{f}}$ & $\boldsymbol{E c} \mathbf{g}^{\mathbf{g}}$ & $\boldsymbol{H} \boldsymbol{p}^{\mathbf{h}}$ \\
\hline Aur $^{\mathbf{i}}$ & 47 & 377 & 189 & 377 & 0.04 & $0.09-0.2$ & 24 & n.d. \\
$\mathbf{1}$ & $4-17$ & $>547$ & $4-9$ & 34 & $0.3-0.5$ & $0.3-0.5$ & 9 & n.d. \\
$\mathbf{2}$ & $9-17$ & $>547$ & 4 & 34 & 0.3 & $0.3-0.5$ & 9 & n.d. \\
$\mathbf{3}$ & $3-6$ & $23-91$ & 3 & 11 & 0.3 & 0.3 & $1-6$ & n.d. \\
$\mathbf{4}$ & $8-16$ & $>503$ & $8-16$ & 31 & 0.5 & $0.2-0.5$ & $8-31$ & n.d. \\
$\mathbf{5}$ & 24 & 189 & 47 & 189 & $0.04-0.09$ & 0.09 & 12 & 0.3 \\
$\mathbf{6}$ & $15-29$ & 464 & 116 & 464 & 0.02 & $0.05-0.1$ & $4-7$ & 0.35 \\
\hline
\end{tabular}

a Acinobacter baumannii NCTC 13420, b Pseudomonas aeruginosa NCTC 13437, c Enterobacter cloacae NCTC 13405,

${ }^{\mathrm{d}}$ Klebsiella pneumoniae ATCC 700603, ${ }^{\mathrm{e}}$ Staphylococcus aureus JE2 (USA300), ${ }^{\mathrm{f}}$ Enterococcus faecium NATCC 700221,

$\mathrm{g}$ Escherichia coli NATCC $25922,{ }^{\mathrm{h}}$ Helicobacter pylori $\mathrm{G} 27,{ }^{\mathrm{i}}$ Auranofin.

\section{Gallium}

The gallium formulation Ganite is an FDA-approved bone resorption inhibitor based on $\mathrm{Ga}\left(\mathrm{NO}_{3}\right)_{3}$ that was recently shown to possess promising activity against several bacterial species such as $P$. aeruginosa, A. baumannii, and M. tuberculosis [50]. Generally, gallium compounds target the iron metabolism of bacteria due to their similarity to iron. When $\mathrm{Ga}(\mathrm{III})$ is incorporated into iron-dependent enzymes, it cannot be reduced to $\mathrm{Ga}(\mathrm{II})$, effectively inhibiting the enzyme. Gallium protoporphyrin IX (GaPPIX, Figure 2) is thought to inhibit the iron metabolism by targeting heme uptake and has been shown to have good activity against both Gram(+) (various methicillin-sensitive S. aureus (MSSA) and MRSA strains, MICs $=0.031-0.062 \mu \mathrm{g} / \mathrm{mL}$ ) and $\operatorname{Gram}(-)$ bacteria (P. aeruginosa, K. pneumoniae, A. baumannii, MICs $=4-16 \mu \mathrm{g} / \mathrm{mL}$ ) [50]. On the other hand, sources of free gallium such as $\mathrm{Ga}\left(\mathrm{NO}_{3}\right)_{3}$ are taken up by siderophore-mediated and/or free iron uptake pathways. A combination of the two types of gallium to achieve maximum effect is therefore desirable. Application of both GaPPIX and $\mathrm{Ga}(\mathrm{NO})_{3}$ resulted in synergetic activity against MRSA and significantly reduced bacterial populations in K. pneumoniae and A. baumannii biofilms [51]. More recently, a topical chitogel-deferiprone GaPPIX treatment was shown to reduce bacterial biomass in S. aureus biofilms in a sheep sinusitis model [52].
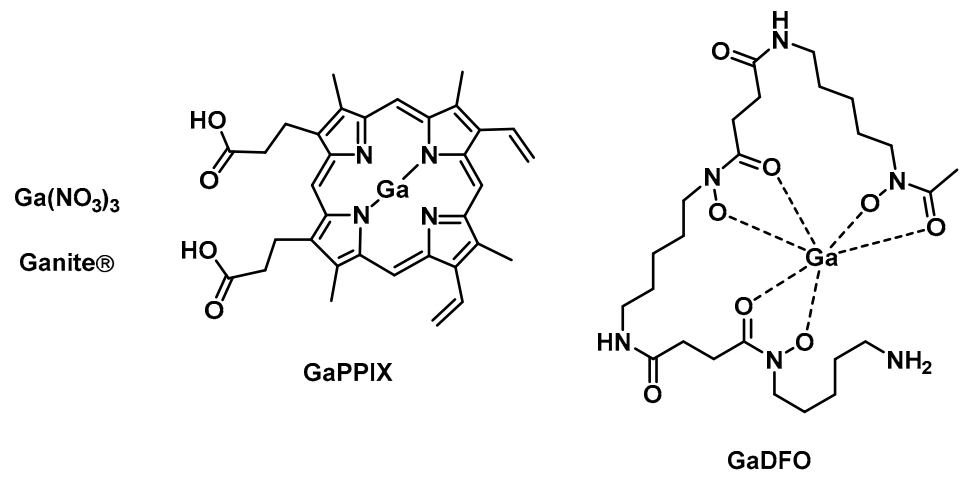

Figure 2. Examples of gallium compounds with antibacterial activities.

Gallium desferrioxamine (GaDFO, Figure 2) was designed to target the iron DFO uptake pathways present in P. aeruginosa [53]. In 2008, Banin et al., reported that GaDFO was able to efficiently kill both planktonic $P$. aeruginosa as well as mature $P$ aeruginosa biofilms. A strong synergetic effect was observed with the antibiotic gentamicin. In vivo studies in a rabbit kerititis model showed that the combination of GaDFO with gentamicin was able to reduce the bacterial infiltration and final scar area by $50 \%-60 \%$. However, it remained unclear whether this reduction was solely attributable to the GaDFO [54]. 
It has to be noted that most studies of the antimicrobial activity of gallium compounds employ iron-poor media, usually via addition of an iron chelator, as high concentrations of iron have been shown to reduce gallium activity. Other work found that the activity is improved further when the studies are conducted in human serum, however exogenous iron addition could nullify gallium compound activity in these cases [50,55]. A comparative study of $\mathrm{Ga}\left(\mathrm{NO}_{3}\right)_{3}, \mathrm{GaPPIX}$ as well as a third gallium-based agent, $\mathrm{Ga}(\mathrm{III})$-maltolate $(\mathrm{GaM})$, investigated the antimicrobial activity of these three compounds against ESKAPE (E. faecium, S. aureus, K. pneumoniae, A. baumannii, P. aeruginosa, and Enterobacter) pathogens under different growth conditions. Importantly, it was shown that the more 'labile' compounds $\mathrm{Ga}\left(\mathrm{NO}_{3}\right)_{3}$ and $\mathrm{GaM}$ lost their antibacterial activity completely in Mueller Hinton broth (MHB) and iron-depleted MHB. GaPPIX showed some bactericidal activity under these conditions against several S. aureus (MICs $=0.06-0.12 \mu \mathrm{M}$ ) and A. baumannii (MICs $=16-32 \mu \mathrm{M}$ ) strains. On the other hand, bacteriostatic activity of $\mathrm{Ga}\left(\mathrm{NO}_{3}\right)_{3}$ and $\mathrm{GaM}$ was found against some strains (mainly A. baumannii and P. aeruginosa) in RPMI-1640 supplemented with 10\% human serum which better simulates the low iron content and presence of human serum in in vivo environments. Conversely, GaPPIX lost all activity against $S$. aureus (MIC $>128 \mu \mathrm{M}$ ) and showed more a more variable profile against A. baumannii (MICs $=0.25-128 \mu \mathrm{M}$ ) [56].

Preliminary in vivo studies by Goss et al., showed that gallium nitrate displayed antibiotic activity in murine lung infections and improved lung function in a preliminary phase I clinical trial, although no placebo control group was used in this study. The group also found that $P$. aeruginosa developed resistance to gallium with similar frequency as to other approved antibiotics [57]. A phase II clinical trial (IGNITE) of gallium nitrate in adults with cystic fibrosis found that there was no significant difference between the number of responders (defined as a participant having a $5 \%$ or greater increase in lung function by day 28) in the intravenous (IV) gallium nitrate and placebo group. However, the study did find that a significantly greater reduction of $P$. aeruginosa was found in the sputum of gallium treated patients compared to the placebo group [58]. Furthermore, gallium nitrate was found to be safe and well tolerated by patients $[57,58]$.

Recently, Pandey et al., described the preparation of a theranostic gallium siderophore ciprofloxacin conjugate. This compound was found to possess good antibacterial activity against both Gram $(+)$ and Gram(-) strains (E. coli K12, S. aureus RN4220, P. aeruginosa PA01, and K. pneunomiae CRE-11; MICs = $0.23-12.5 \mu \mathrm{M})$ in iron-deficient media. By using radioactive ${ }^{67} \mathrm{Ga}$, the group was able to follow the metabolic fate of the compound in mice, opening up the door for potential theranostic applications, with both diagnostic and therapeutic benefits in bacterial infections [59].

Despite these promising results, there is a general lack of knowledge around the exact molecular mechanisms of action of gallium-based compounds. As mentioned earlier, $\mathrm{Ga}$ (III) has very similar properties to $\mathrm{Fe}(\mathrm{III})$ and can disrupt a variety of iron-dependent functions as it cannot be reduced under physiological conditions [60]. Recent studies by the group of Hongzhe Sun elucidated the molecular targets of gallium. By integrating metalloproteomics with metalbolomics and transcriptomics, the group identified $P a R p o B$ and $P a R p o C$ as binding sites for gallium nitrate in P. aeruginosa. The targets were validated by overexpressing the respective genes in E. coli. Only cells with $P a R p o B$ and PaRpoC could be fluorescently labelled by the group's Ga(III) probe. These proteins are two subunits of the DNA-dependent RNA polymerase, an essential enzyme in transcription and gene expression. Through cellular thermal shift assays, these proteins were found to be destabilized upon binding to gallium. By adding different concentrations of exogenous metabolites, the group found that acetate in combination with gallium seemed to increase its antibacterial potency. Indeed, this combination treatment increased the uptake of gallium into the bacteria significantly. This effect could also be replicated in cell and murine infection models, indicating a potentially promising combination therapy for bacterial infections [61].

Analogous to silver, it seems that the antibacterial effect of gallium compounds stems from the binding of the free $\mathrm{Ga}(\mathrm{III})$ ion to specific targets in bacteria. Preparation of stable or semi-stable gallium coordination complexes could improve the availability and uptake of gallium. These ligands 
should still allow for a dissociation of the gallium core once the compound has entered the bacteria. To increase bacterial specificity, ligands which allow for derivatization (e.g., with targeting units) are therefore desirable.

\section{Bismuth}

Another metal that has long been known to possess beneficial medicinal properties is bismuth. Similarly to silver and gallium, however, the molecular mechanism of bismuth-based compounds has remained elusive for a long time. Bi(III) exhibits remarkably low toxicity against humans while being potently toxic against bacteria. Bismuth and its complexes have reportedly been used in the treatment of syphilis, colitis wound infection and quartan malaria. Its most prominent use to date however is for gastrointestinal disorders [62]. H. pylori has been shown to be particularly susceptible to bismuth, with three drugs, bismuth subsalicylate (Pepto-Bismol), colloidal bismuth subcitrate (CBS, De-Nol, Figure 3), and ranitidine bismuth citrate (Pylorid), used to treat their infections [63,64]. Bismuth compounds with antimicrobial and anticancer activities have been reviewed recently [65]. The group of Sun and co-workers uncovered that glutathione binds Bi(III) in human cells and compartmentalizes it into subcellular vesicles, effectively removing it from intra- and extracellular compartments. [66] Over the years, the use of GE-ICP-MS techniques and customized fluorescent probes has facilitated the identification of a number of Bi-binding proteins. Evidence points to multiple modes of action with several targets, which is in agreement with the low resistance frequency found with bismuth compounds [67]. In 2018, the group of Sun described a repurposed application of the bismuth drug CBS. The compound was shown to irreversibly inhibit the metallo- $\beta$-lactamases (MBL) such as New Delhi MBLs (NDMs), Verona integron-encoded MBLs (VIMs), and imipenemases (IMPs). Crystallography studies revealed that Bi(III) can replace one of the $\mathrm{Zn}$ (II) ions in the active site of MBLs. Furthermore, cotreatment of CBS with meropenem restored efficacy in vitro and in vivo and significantly slowed down further resistance development in NDM-1 positive E. coli bacteria [68]. Since CBS is already a clinically approved drug and has proven safe in humans at high doses, its path to approval as a MBL inhibitor may be facilitated. At the same time the wealth of recent molecular insights into the modes of action of bismuth will allow for the development of more rationally designed compounds that may display even better activity profiles.

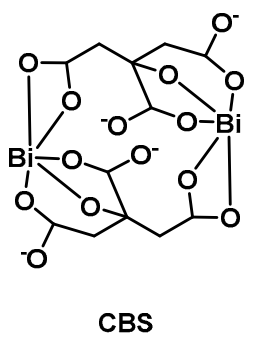

Figure 3. Structure of colloidal bismuth subcitrate (CBS).

\section{Ruthenium}

Ruthenium complexes have been widely studied for their biological activity, particularly their anticancer properties. Labile ruthenium complexes have been shown to bind nucleic acids coordinatively through ligand exchange reactions. On the other hand, inert compounds, generally bearing one or more polypyridyl ligand(s) can bind DNA and RNA through intercalation [20,21]. The biological properties of ruthenium, including some interesting antimicrobial properties were already described in the 1950s [69]. Amongst several transition metals tested, it was shown that $\left[\mathrm{Ru}\left(\mathrm{Me}_{4} \mathrm{phen}\right)_{3}\right]^{2+}(7$, Figure 4) showed remarkable antimicrobial activity in vitro. However, it was also noted that the compounds were not effective in vivo due to rapid clearance following IV administration in mice, leading the authors to suggest topical applications. Interestingly only minimal increases in MIC were detected after 25 passages with the ruthenium complex 7, compared to over a 10'000-fold increase 
in MIC with penicillin against Streptococcus pyogenes, highlighting potential benefits of ruthenium-based antibiotics with regards to their propensity to induce resistance [70-72].
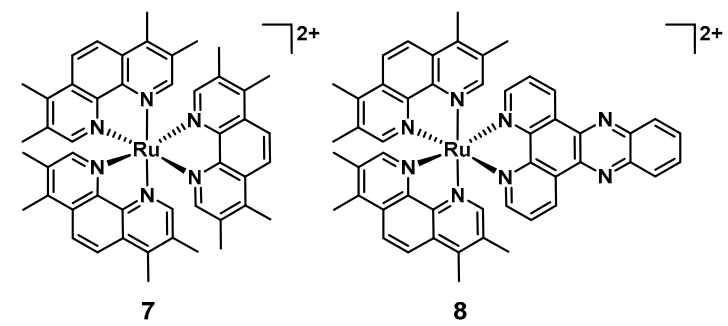

Figure 4. Structures of $\left[\mathrm{Ru}\left(\mathrm{Me}_{4} \mathrm{phen}\right)_{3}\right]^{2+}(7)$ and $\left[\mathrm{Ru}\left(2,9-\mathrm{Me}_{2} \mathrm{phen}\right)_{2}(\mathrm{dppz})\right]^{2+}(8)$.

In 2011 Aldrich-Wright and co-workers reported that $\left[\mathrm{Ru}\left(2,9-\mathrm{Me}_{2} \text { phen }\right)_{2}(\mathrm{dppz})\right]^{2+}(8$, Figure 4$)$ possessed activity against a range of Gram(+) bacteria (MSSA, MRSA, and Bacillus subtilis MICs = $2-8 \mu \mathrm{g} / \mathrm{mL}$ ) in vitro and in vivo, increasing the survival of a $S$. aureus-infected Caenorhabditis elegans population when supplied at doses of $8 \mu \mathrm{g} / \mathrm{mL}$ or higher. These compounds have been shown to be able to bind DNA through intercalation, however it remains unclear whether this is their effective mode of action. Importantly, the tested compound was not toxic to C. elegans. On the other hand, no activity was observed against E. coli. [73].

Ruthenium polypyridyl complexes can also act as photosensitizers, generating ROS upon light irradiation, an approach which is known as antibacterial photodynamic therapy (aPDT) in the realm of infectious disease treatments [74]. ROS can damage enzymes, proteins, DNA and/or RNA if they are generated in their close proximity. The propensity of these complexes to bind DNA/RNA makes these likely targets for this class of ruthenium compounds. The potential for aPDT is particularly promising for localized infections, where conventionally a systemic antibiotic would be administered [75]. Traditional targets include skin and wound infections but thanks to advances in endoscopes and fiber optic devices, most body areas e.g., ear, nose oral cavity, gastrointestinal tract, urogenital tract, and lungs are now accessible to localized light irradiation for aPDT [76]. Furthermore, early studies into the resistance induction of aPDT have found little to no resistance development in treated bacterial strains [77].

Donnely et al., were amongst the first to report the aPDT potential of a ruthenium polypyridyl (9, Figure 5) complex in 2007. The compounds showed MIC values of $12.5 \mu \mathrm{g} / \mathrm{mL}, 50 \mu \mathrm{g} / \mathrm{mL}$, and $\leq 12.5 \mu \mathrm{g} / \mathrm{mL}$ against $S$. aureus, P. aeruginosa, and C. albicans, respectively, upon white light irradiation. Unfortunately, no toxicity studies against human cell lines were reported [78]. The group of Gasser reported complexes with light-mediated activity against bacteria in 2014. Compound 10 showed good activity against $S$. aureus ( $>6 \log$ reduction at $50 \mu \mathrm{M})$, while 11 was active against both S. aureus and E. coli when irradiated with $420 \mathrm{~nm}$ light (>6 log reduction at $50 \mu \mathrm{M}$; Figure 5) [79]. No activity was observed in the absence of light. However, 10 showed activity against both normal lung fibroblasts $\left(\mathrm{MRC}-5, \mathrm{IC}_{50}=15.6 \mu \mathrm{M}\right)$ and human cervical carcinoma cells $\left(\mathrm{HeLa}, \mathrm{IC}_{50}=5.7 \mu \mathrm{M}\right)$ after $48 \mathrm{~h}$ of incubation in the dark (11 was nontoxic up to $100 \mu \mathrm{M}$ in the absence of light). More recently, Le Gall et al., reported a structure-activity relationship of 17 different light-activated ruthenium complexes (12 is shown as an illustrative example, Figure 5) with a range of activity profiles against various Gram(+) and Gram(-) strains (12 led to a $5 \mathrm{log}$ reduction in growth in both S. aureus RN4220 and MRSA N315) [80]. In 2019 Feng et al., described a series of charged ruthenium complexes that showed good activity against $S$. aureus and MRSA upon light irradiation (only minor activity against Gram(-) E. coli was found). The most highly charged complex $\mathbf{1 3}$ was shown to possess the best antibacterial activity, displaying 6-7 log reduction in bacterial viability (comparable to methicillin and vancomycin at equal concentrations). Scanning electron microscopy (SEM) experiments revealed damaged and deformed cell walls in S. aureus, pointing to the highly negatively charged bacterial surface as the 
target of this class of compounds. Interestingly, co-culture experiments revealed preferential killing of bacterial cells over mammalian cells in vitro [81].
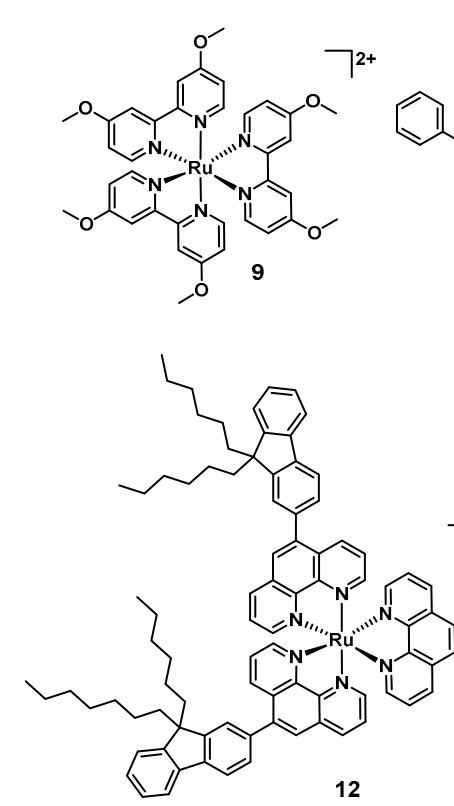

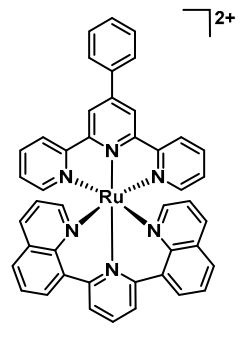

11

10

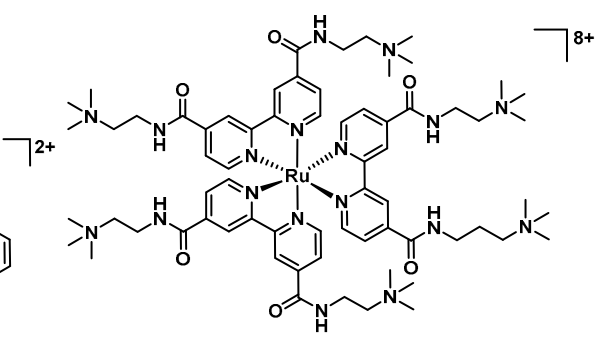

13

Figure 5. Structures of aPDT-active ruthenium polypyridyl complexes.

Overall, most reported ruthenium aPDT agents (except 10) possess an overall positive charge, which may promote interactions with the negatively charged bacterial membrane.

Smith and Zhang et al., pursued a different light-mediated strategy, preparing a ruthenium complex (14, Figure 6) where a ligand, namely the anti-tuberculosis drug isoniazid, is released upon light irradiation $465 \mathrm{~nm}$. This compound was found to be inactive against E. coli and B. subtilis but highly selective towards Mycobacterium smegmatis, where a survival of $<1 \%$ was observed at $10 \mu \mathrm{M}$ upon light irradiation $\left(\mathrm{MIC}_{M}\right.$. smegmatis $=4 \mu \mathrm{M}, \mathrm{MIC}(\text { isoniazid })_{M}$. smegmatis $\left.=29 \mu \mathrm{M}\right)$. At the same time, the compound was found to be non-toxic to mammalian cells ( $>90 \%$ survival of MRC- 5 cells at $200 \mu \mathrm{M})[82]$.
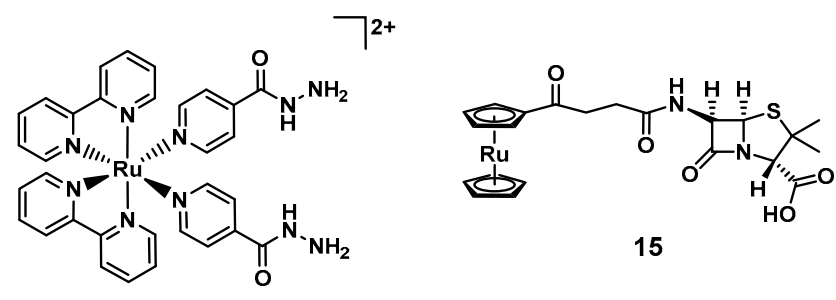

14

Figure 6. Ruthenium polypyridyl complex with light-triggered isoniazid ligand release (14) and a ruthenocene derivative of a $\beta$-lactam (15).

In a different approach, ruthenocene was conjugated to the $\beta$-lactam 6-aminopenicilinic acid. The resulting complex (15, Figure 6) showed antibacterial activity against a range of MSSA clinical isolates, S. epidermidis, and E. faecalis, with MIC values ranging from 0.5 to $16 \mu \mathrm{g} / \mathrm{mL}$. No activity was observed against MRSA (MIC $=256 \mu \mathrm{g} / \mathrm{mL}$ ) [83]. Interestingly the corresponding ferrocene analogue displayed lower activity, potentially due to its higher susceptibility to oxidation [84]. The authors were also able to obtain a co-crystal structure of 9 with CTX-M $\beta$-lactamase at $1.18 \AA$ resolution. This highlights another advantage that metal-complexes offer: Their increased propensity for crystallization with higher associated electron density of the metal center facilitates the resolution of protein target structures. 
The first investigations into the antibacterial properties of dinuclear ruthenium complexes of the type $\left.\left[\mathrm{Ru}_{2} \text { (phen }\right)_{4}\left(\mu-\mathrm{bb}_{\mathrm{n}}\right)_{2}\right]^{4+}\left(\mathrm{bb}_{\mathrm{n}}=\right.$ bis $\left[4\left(4^{\prime}\right.\right.$-methyl-2,2'-bipyridyl)]-1,n-alkane, $\mathbf{1 6}_{\mathbf{n}}$, Figure 7$)$ were published by the groups of Collins and Keene in 2011. The group was able to isolate both the $\Delta \Delta$ and $\Lambda \Lambda$ enantiomers, observing slight differences in their antibacterial profile. The compounds were found to be active against both $\operatorname{Gram}(+)$ and $\operatorname{Gram}(-)$ bacteria as soon as the alkyl chain reached a certain length (e.g., for $\Lambda \mathbf{\Lambda 1 6} \mathbf{1}_{\mathbf{7}}: \mathrm{MIC}_{\text {S. aureus }}=64 \mu \mathrm{g} / \mathrm{mL}$, and for $\Lambda \mathbf{\Lambda 1 6} \mathbf{1 0}_{\mathbf{1 0}}: \mathrm{MIC}_{\text {S } \text { aureus }}=8 \mu \mathrm{g} / \mathrm{mL}$ ), with somewhat lower activity against Gram(-) bacteria. Overall, the compounds showed significantly lower toxicity towards human acute monocytic leukemia cells (THP-1, model for nucleated eukaryotic cells) [85]. In following work, the authors found that longer alkyl chain length correlated positively with higher cellular uptake. As the longer chain length leads to more lipophilic compounds, the authors concluded that this increase in lipophilicity is responsible for the higher uptake [86]. Later studies showed that $\mathbf{1 0}_{16}$ preferentially binds RNA in live bacteria and accumulates at the ribosomes, condensing them when they form polysomes. This finding suggests that the compounds halt translation of RNA and thereby protein synthesis in bacteria [87]. The group then went on to investigate the corresponding tri- and tetra-nuclear ruthenium compounds $\left(\mathbf{1 7}_{\mathbf{n}}\right.$ and $\mathbf{1 8}_{\mathbf{n}}$, Figure $\left.\mathbf{7}\right)$, showing that these complexes showed up to four-fold better activity compared to the dinuclear ones. Extensive NMR studies and molecular dynamics simulations revealed that complex $\mathbf{1 7}_{\mathbf{1 2}}$ could insert into a negatively charged phospholipid bilayer mimic of a bacterial membrane, suggesting membrane disruption as a possible mode of action of this class of compounds. Interestingly, no insertion was observed with eukaryotic membranes [88]. Generally, slightly lower activity was observed in Gram(-) strains compared to Gram(+) ones, even though the cellular accumulation was found to be similar [89]. Amongst these, $P$. aeruginosa was found to be notably less sensitive to these inert polynuclear ruthenium complexes despite similar cellular accumulation, indicating some inherent resistance to these compounds by this strain $[72,90]$.

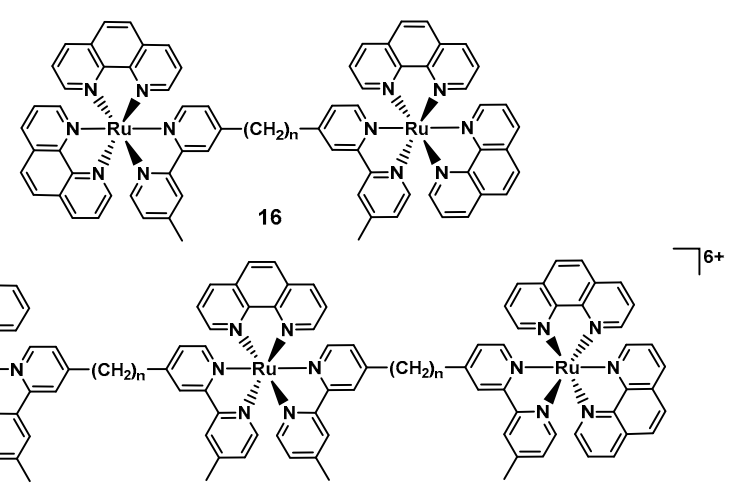

17

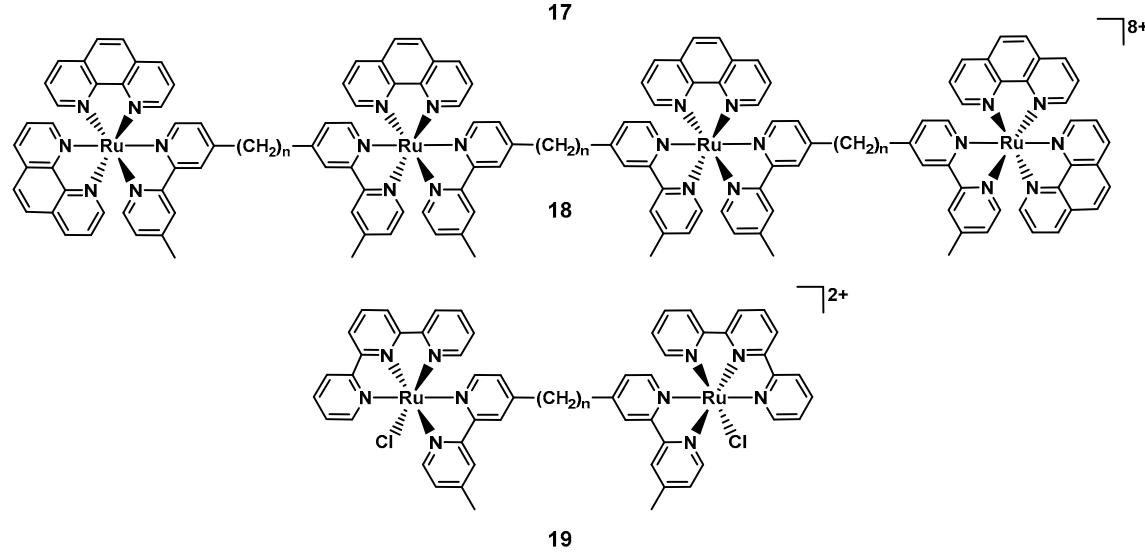

Figure 7. Example structures of the polynuclear ruthenium complexes reported by the groups of Keene and Collins ( $n$ indicates the length of the alkyl chain). 
The same group also reported on dinuclear ruthenium complexes of the type $\left[\mathrm{Ru}_{2}(\mathrm{tpy})_{2}\left(\mu-\mathrm{bb}_{\mathrm{n}}\right) \mathrm{Cl}_{2}\right]^{2+}$ (tpy $=2,2^{\prime}: 6^{\prime}, 2^{\prime \prime}$-terpyridine, 19, Figure 7), where the labile chlorido ligand is aquated in solution generating a more highly charged complex. The compounds with a linker chain length of 7, 12 or 14 showed good antibacterial activity with MIC values between 1 and $8 \mu \mathrm{g} / \mathrm{mL}$ against MSSA, MRSA, and E. coli. Overall, the authors reported slightly reduced uptake and a concurrent small reduction in activity compared to the inert analogous complexes. This suggests that there is a fine balance between charge, charge separation and lipophility that ultimately affects both cellular uptake and antibacterial activity [91]. It also indicates that we do not understand the structure activity relationships of these compounds well enough yet to make predictions about what factors are decisive in a metal complex's antibiotic activity.

In 2019, Smitten et al., reported the remarkable antimicrobial activity of a dinuclear ruthenium complex (20, Figure 8). This complex showed good antibacterial activity against pathogenic, multidrug resistant Gram(-) bacteria (E. coli and E. faecalis, MICs $=0.5-1.6 \mu \mathrm{M}$ ), while showing no significant cytotoxicity against eukaryotic cells $\left(\mathrm{IC}_{50}=135 \mu \mathrm{M}, \mathrm{HEK} 293\right)$. The authors showed that the complex could disrupt the Gram(-) membranes, as evidenced by changes in cell morphology and lump formation after $20 \mathrm{~min}$. The compound seemed to accumulate at the cell poles, similarly to what had been reported for the polynuclear ruthenium complexes by Keene and Collins [92]. In follow-up work, 20 was shown to possess increased in vitro activity against $S$. aureus (SH1000) in chemically defined minimal media $(\mathrm{CDM}, \mathrm{MIC}=4 \mu \mathrm{M})$ compared to the more commonly used Mueller-Hinton-II media (MH-II, MIC $=40 \mu \mathrm{M}$ ), possibly due to more interactions with media substrates in the latter. STED nanoscopy, membrane damage assays and transmission electron microscopy studies suggest that the compound targeted both the bacterial membrane as well as the DNA-content of the cells in S. aureus. Furthermore it was shown that in contrast to the results with $\operatorname{Gram}(-)$ strains, 20 showed decreased activity against MRSA and an antimicrobial resistant (AMR) clinical isolate. The authors went on to conduct experiments with mutated $S$. aureus strains. The tarO strain is deficient in wall teichoic acids and the $d l t A$ strain is specifically deficient in $D$-alanylated teichoic acids. The MICs against both mutants were lower than against the original SH1000 strain, suggesting that $\mathbf{2 0}$ could potentially be binding to teichoic acids within the Gram $(+)$ cell wall, reducing its ability to penetrate the bacteria and lowering its potency. Up-regulation of $m p r F$ has been found to be a frequent resistance mechanism in S. aureus against membrane active agents [93]. This upregulation results in a higher concentration of positive charges on the outer cytoplasmic membrane of $S$. aureus and reduces susceptibility to cationic compounds. The MIC against the $S$. aureus $\Delta m p r F$ strain was significantly lower $(1.5 \mu \mathrm{M})$ than in the SH1000 strain $(40 \mu \mathrm{M})$ [94]. Altogether this study showed that the lower susceptibility of the drug-resistant Gram(+) S. aureus to 20 compared to the Gram(-) strains can be attributed to their different molecular membrane structures of these bacteria. These insights will be helpful in the design of the next generation of ruthenium-based antibacterial agents.

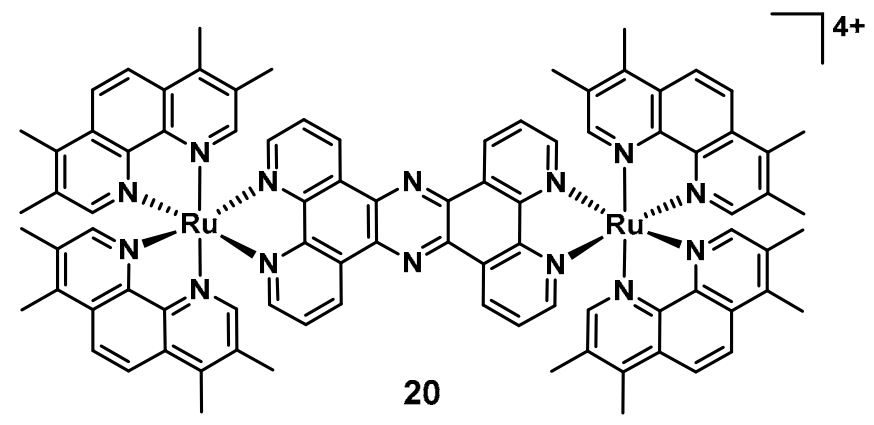

Figure 8. The dinuclear, tetracationic ruthenium polypyridyl complex reported by Smitten et al. [94].

Overall the prominent role of ruthenium in anticancer applications has somewhat carried over to antimicrobial applications, making it one of the more intensely investigated elements in this field. The more detailed mode of action studies that have appeared in recent years provide promising 
groundwork towards understanding how these complexes work and designing the next generation of compounds. For ruthenium complexes to be developed further, in vivo efficacy experiments will be imperative, as there are only very limited data available at this stage and future research will have to focus on this area.

\section{Iridium}

In the aforementioned reports on chlorido-substituted dinuclear ruthenium polypyridyl complexes, the authors also prepared the analogous iridium compounds. Interestingly the iridium compounds showed some degree of inhibitory activity but further studies revealed that the complexes were bacteriostatic as compared to the bactericidal ruthenium counterparts [91]. The origin of the difference in activities between the two metals is unknown at this stage. The $\operatorname{Ir}(\mathrm{III})$ compounds possess an overall charge of +4 before aquation of the chloride ligand (compared to +2 for the $\mathrm{Ru}$ (II) complexes), which may affect their ability to penetrate the bacteria. Furthermore, the chlorides of the iridium complexes were found to be more labile than the ruthenium one, suggesting that these compounds actually possess a +6 charge in solution, which might prevent high enough accumulation for bactericidal activity. In subsequent work, analogous iridium compounds generally performed worse than the ruthenium complexes, showing either lower or no antibacterial activity at all [95]. In 2015, Lu et al., reported on cyclometallated polypyridyl iridium complexes (21, Figure 9) that showed promising activity against S. aureus, but none against E. coli, E. faecalis, and K. pneuomonia. However, the most antibacterial compound $\left(21, \mathrm{MIC}_{S \text {. aureus }}=3.6 \mu \mathrm{M}\right)$ was similarly cytotoxic against cancer cells, suggesting a non-specific toxic mode of action [96]. The same year, Jain et al., described another series of iridium(III) complexes with 22 showing promising activity against $E$. coli and B. subtilis $\left(\mathrm{MIC}_{B \text {. subtilis }}=4 \mu \mathrm{g} / \mathrm{mL}\right.$, $\mathrm{MIC}_{E \text {. coli }}=4 \mu \mathrm{g} / \mathrm{mL}$ ) and demonstrated the ability to intercalate DNA [97]. A different cyclometallated iridium(III) dipyridylamine complex conjugated to biotin (23) was shown to effectively kill P. aeruginosa, a notoriously hard to kill Gram(-) species (MIC $=4 \mu \mathrm{g} / \mathrm{mL}$ ). Two other analogues with no conjugated unit or a glycoside attached showed no activity against these bacteria. Upon irradiation with blue light, these two complexes decreased the survival of P. aeruginosa down to $2 \pm 1 \%$ (methyl substituted) and 6 $\pm 2 \%$ (glycoside substituted) while the biotin conjugate showed no significant decrease in bacterial survival [98]. Some cyclometallated Ir(III) complexes are known to act as photosensitizers, generating ROS upon light irradiation, making them potential candidates for aPDT as well [99]. This work seems to indicate that biotin conjugation may be another possibility to improve bacterial uptake of metal complexes to further improve their activity.

The groups of Falkinham and Merola have previously investigated piano-stool type complexes of iridium and rhodium with amino acid ligands for their antimycobacterial activity, reporting better activity for the complexes bearing hydrophobic amino acids. The presence of a cyclopentadiene (Cp) ligand was also found to correlate with better antimycobacterial activity [100]. Follow up studies reported a series of pentaalkylcyclopentadienyl iridium and two cobalt complexes with three iridium and one cobalt compound possessing promising activity against nine $S$. aureus strains, including seven MRSA strains derived from patients and laboratories $(\mathbf{2 4}, \mathrm{MICs}=4-8 \mu \mathrm{g} / \mathrm{mL}$, Figure 9$)$. The active iridium complexes did not show any cytotoxicity against the Vero cell line ATCC CCL-81 up to $500 \mu \mathrm{g} / \mathrm{mL}$ or hemolytic properties up to $250 \mu \mathrm{g} / \mathrm{mL}$. Complex 24 was further described as non-toxic in mice at doses of $5 \mathrm{mg} / \mathrm{kg}$, however no experimental details were disclosed [101]. More recently, the same authors reported a new series of piano-stool iridium diamino-type complexes that showed activity against a $S$. aureus as well as a MRSA strain while displaying no toxicity in vitro and in vivo (25, MICs $=5-7.5 \mathrm{ug} / \mathrm{mL}$, Figure 9). It was shown that the free diaminocyclohexane ligand did not possess any activity, hence the observed effect was attributed to the complex itself. Their exemplary study demonstrating the safety of a metal-based antibiotic in mice represents one of the first of their kind for iridium antibacterial agents. The complex did not cause any acute effects when given as a single IV dose at 2.5 and $5 \mathrm{mg} / \mathrm{kg}$ to adult outbred white mice (ICR strain), and the animals displayed normal growth, health, and behavior in the following 14 days. Through ICP-OES it was shown that 
the iridium compounds were excreted efficiently through their urine and no iridium was detectable following sacrifice of the mice on day 14. No data on in vivo efficacy was reported in this study [102].

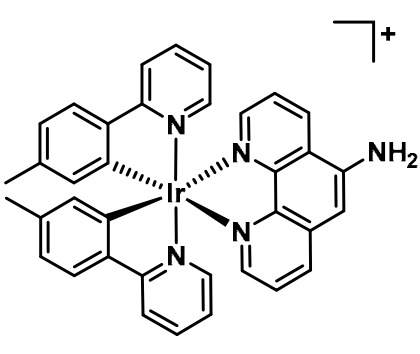

21<smiles>[PH3][P+](c1ccccc1)(c1cc2ccccc2cc1-c1ccccc1)C(Cl)(Cl)c1ccccc1</smiles>

22

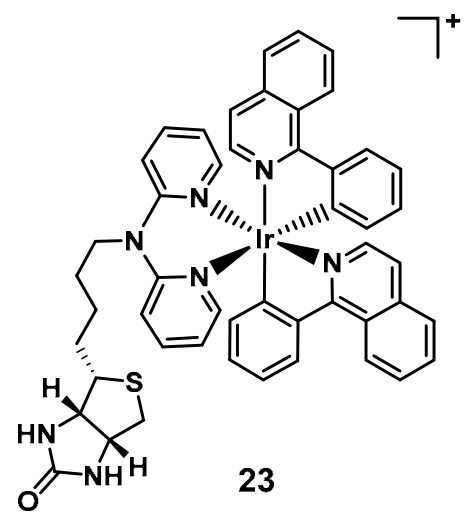

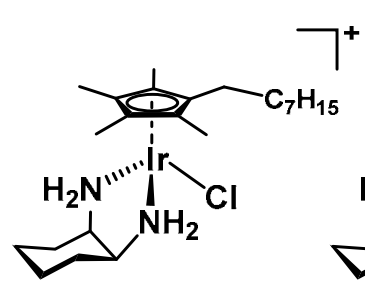

24

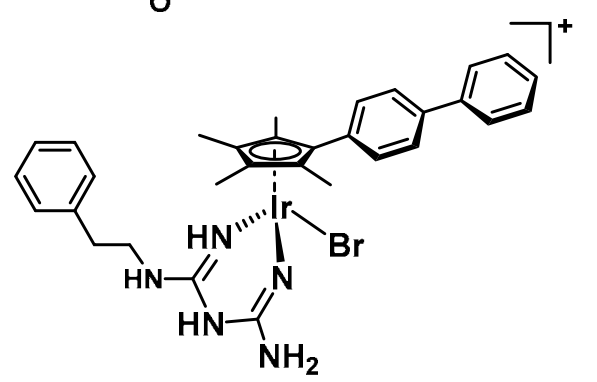

26

Figure 9. Selected iridium-based antibacterial complexes.

Finally, the group of Sadler reported a series of 14 organoiridium(III) complexes in 2018. Compounds in this series displayed excellent activity against MRSA and differential activity against E. coli and A. baumanii. Only one compound, 26, showed activity against K. pneumoniae $\left(\mathrm{MIC}_{E}\right.$. coli $=$ $9.3 \mu \mathrm{M}, \mathrm{MIC}_{K \text {. pneumoniae }}=9.3 \mu \mathrm{M}, \mathrm{MIC}_{A}$. baumanii $=4.7 \mu \mathrm{M}, \mathrm{MIC}_{M R S A}=1.2 \mu \mathrm{M}$, Figure 9) and no activity was reported against $P$. aeruginosa. Three complexes showed synergistic activity when co-administered with the antibiotic vancomycin against vancomycin resistant Enterococci. Moreover, a subset of the compounds also exhibited good activity against the fungal strain C. albicans and C. neoformans. Some compounds could also disrupt $S$. aureus biofilm formation [103]. Comparison of the structures of the 14 complexes reveal that the biphenyl-Cp ligand is essential, as the pentamethyl-Cp or the mono-phenyl-Cp showed greatly diminished antibacterial activity. Similarly, the biguanine ligand on its own was also not active, indicating that the overall structure of the complex plus the iridium centre are required for the observed biological action. The authors found that the antibacterial activity of the complexes was very similar under aerobic and anaerobic conditions against S. aureus and S. pyogenes, indicating that ROS generation is not required for their antimicrobial effect. Further essays showed that bacterial cell envelopes remained intact upon treatment with the iridium compounds. Finally the authors hypothesize that Ir(III) biguanine complexes could enter bacteria and then undergo ligand exchange reactions with thiol-containing biomolecules, releasing the biguanide ligands, which might interfere with cell processes inside the bacteria [103].

Iridium complexes seem to have good antimicrobial potential, however, the cost of the element is similar to the cost of gold [104]. As antibiotics are generally taken in quite high doses and are not priced as highly as e.g., anti-cancer treatments, iridium-antibiotics are unlikely to be commercially viable. Nevertheless, as a last resort, a super-effective iridium antibiotic would be better than no option at all. 


\section{Rhenium}

Rhenium complexes have slowly but steadily gained attention for their medicinal applications. A couple of reviews on their anticancer properties have recently been published $[105,106]$. In line with what is generally true for the field, their antimicrobial activities have only been studied sparsely. The groups of Metzler-Nolte and Bandow reported a series of studies into the structure-activity relationship of a group of trimetallic complexes. Amongst these compounds, 27 showed excellent activity against Gram(+) bacteria, including MRSA (Figure 10). The authors also found that the $\left[(\mathrm{dpa}) \operatorname{Re}(\mathrm{CO})_{3}\right]$ moiety was crucial for the observed activity $[107,108]$. Further experiments revealed that this class of compounds disturbed processes at the bacterial cell membrane such as respiration and cell wall biosynthesis [109]. Inspired by these results, we recently investigated bisquinoline rhenium tricarbonyl complexes for their antibacterial properties. The most promising compound (28, Figure 10), showed good activity against MSSA and MRSA (MIC $=4-8 \mu \mathrm{g} / \mathrm{mL})$, but was inactive against Gram(-) bacteria. Upon light irradiation at $365 \mathrm{~nm}$, the activity of the compound increased significantly, the effect also imparting Gram(-) activity against wildtype and colistin-resistant E. coli (MIC $=4-8 \mu \mathrm{g} / \mathrm{mL}$ ). The compound showed no haemolytic properties and a 20-fold lower toxicity against human HEK cells compared to its MIC against $S$. aureus. The distinct activity profile in the absence and presence of light indicates a dual-mode of action [110]. In 2017 Siegmund et al., described the preparation of novel Re(I) N-heterocyclic carbene (NHC) complexes. These compounds were found to possess potent antibacterial activity against $\operatorname{Gram}(+)$ strains, while being inactive against Gram(-) ones (29 shown as example, $\mathrm{MIC}_{B \text {. subtilis }}=0.7-1.3 \mu \mathrm{M}, \mathrm{MIC}_{S \text {. aureus }}=0.7 \mu \mathrm{M}$, Figure 10) [111]. This new class of rhenium complexes has also been patented by the groups and is currently being developed further [112].

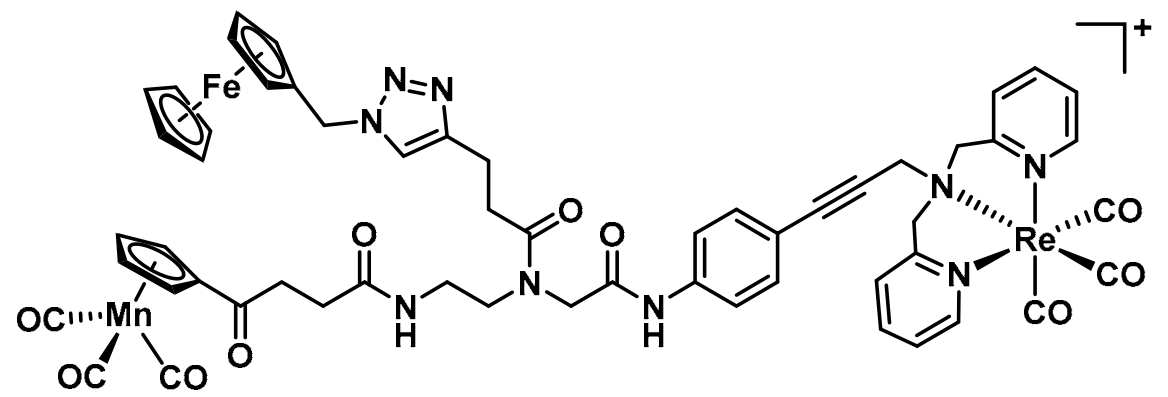

27

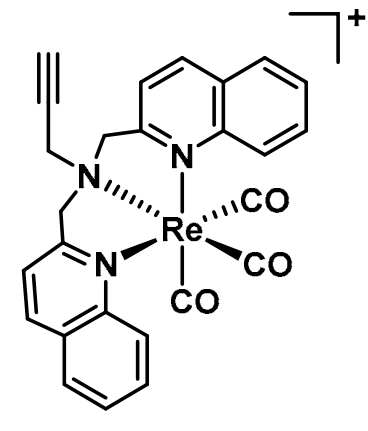

28<smiles>C[CH+](C)C(=O)[C@](C)(C=O)c1nc2ccccc2[nH]1</smiles>

29

Figure 10. Structures of rhenium complexes with reported antimicrobial activity.

While still in its infancy, rhenium has proven itself a promising starting point for the development of new classes of antibacterial agents, in particular against Gram(+) strains. Again, there is a still total lack of in vivo data for this class of compounds which will have to be addressed in future studies. 


\section{Metal Complexes vs. Organic Molecules}

It is evident that the tip of the iceberg has only barely been scratched when it comes to investigating the antimicrobial potential of metal complexes (Table 2).

Table 2. Overview of metal complexes discussed in this article.

\begin{tabular}{|c|c|c|c|c|c|c|c|c|}
\hline Compound & $\#^{a}$ & Metal & $G(+)^{b}$ & $G(-)^{c}$ & Media $^{d}$ & Target/MoA ${ }^{\mathrm{e}}$ & Cytotoxicity ${ }^{f}$ & In vivo $\mathrm{g}$ \\
\hline $\mathrm{AgNO}_{3}[113]$ & 1 & $\mathrm{Ag}$ & Yes & Yes & LB & TCA cycle & Yes (Yes) & Yes (human) \\
\hline Aur [15] & 1 & $\mathrm{Au}$ & Yes & No & CAMBH & Trx inhibition & Yes (Yes) & Yes (mouse) \\
\hline Ganite [50] & 1 & $\mathrm{Ga}$ & No & Yes & MH; HS & Fe-metabolism [61] & Yes (No) & Yes (human) \\
\hline Ga(DFO) [53] & 1 & Ga & n.d. & Yes & TSB & Fe-metabolism [61] & Yes (No) & Yes (rabbit) \\
\hline Ga(PPIX) [51] & 1 & $\mathrm{Ga}$ & Yes & Yes & LB, MHB, DMHB, RPMI-HS & $\begin{array}{c}\text { Fe-metabolism [61] } \\
\text { Cytochrome [114] }\end{array}$ & Yes (No) & Yes (sheep) \\
\hline CBS [64] & 1 & $\mathrm{Bi}$ & Yes & Yes & TSB & Multiple targets and MBLs [64] & Yes (No) & Yes \\
\hline $7[70]$ & 10 & $\mathrm{Ru}$ & Yes & n.d. & DFH & n.d. & Yes (Yes) & Yes (mouse) \\
\hline $8[73]$ & 3 & $\mathrm{Ru}$ & Yes & No & LB, BHI & DNA intercalation & n.d. & Yes (fungi) \\
\hline $9[78]$ & 3 & $\mathrm{Ru}$ & Yes & Yes & MH & PDT & n.d. & n.d. \\
\hline $10[79]$ & 1 & $\mathrm{Ru}$ & Yes & No & MH & PDT & Yes (No) & n.d. \\
\hline 14 [82] & 1 & $\mathrm{Ru}$ & No & No & TSB & Light-triggered isoniazid release & Yes (No) & n.d \\
\hline $15[83]$ & 2 & $\mathrm{Ru}$ & Yes & Yes & CAMBH & $\beta$-lactamase & n.d. & n.d. \\
\hline 16 [85] & 26 & $\mathrm{Ru}$ & Yes & Yes & CAMBH & RNA, ribosome & Yes (Some) & n.d. \\
\hline $\mathbf{1 7 - 1 8}$ [89] & 14 & $\mathrm{Ru}$ & Yes & Yes & CAMBH & Bacterial membrane & Yes (Some) & n.d. \\
\hline 19 [91] & 3 & $\mathrm{Ru}$ & Yes & Yes & CAMBH & Bacterial membrane & Yes (Some) & n.d. \\
\hline $20[92]$ & 4 & $\mathrm{Ru}$ & Yes & Yes & CAMBH CDM & Bacterial membrane, DNA & Yes (No) & Yes (moth) \\
\hline $21[96]$ & 5 & Ir & Yes & No & LB & Not studied & Yes (Yes) & n.d. \\
\hline $22[97]$ & 6 & $\mathrm{Ir}$ & Yes & Yes & MH & Binds DNA & n.d. & n.d. \\
\hline 23 [99] & 3 & $\mathrm{Ir}$ & n.d. & Yes & LB & Not studied & n.d. & n.d. \\
\hline 24 [101] & 16 & $\mathrm{Ir}$ & Yes & n.d. & $\mathrm{MH}$ & Not studied & Yes (No) & n.d. \\
\hline
\end{tabular}

${ }^{a}$ Number of compounds reported in the cited study; ${ }^{b}$ Whether the compounds were active against any Gram $(+)$ strains; ${ }^{\mathrm{c}}$ Whether the compounds were active against any $\operatorname{Gram}(-)$ strains; ${ }^{\mathrm{d}}$ growth media used for antibacterial activity determination; ${ }^{\mathrm{e}}$ Putative target and or mode of action (MoA) for the compound(s); ${ }^{\mathrm{f}}$ Whether cytotoxicity against human cells was determined (if it was found to be cytotoxic). Note: For this article a compound was considered cytotoxic if the CC 50 or IC 50 was $<50 \mu \mathrm{M}$. It is noted that most compounds were tested against different cell lines and the reader is referred to the cited publications for further details. ${ }^{g}$ Whether the compounds were evaluated in vivo (animal model). n.d.: not determined LB: Lysogeny broth; CAMBH: cation-adjusted Mueller-Hinton broth; MH: Mueller-Hinton broth; HS: human serum; TSP: tryptic soy broth; DFH: Difco heart-infusion broth $+10 \%$ horse serum; BHI: Brain Heart Infusion broth; CDM: Chemically defined medium; MBL: metallo- $\beta$-lactamases; PDT: photodynamic therapy.

Although there have been in vitro studies into many other elements, including chromium [115], iron [116], manganese [117-120], copper [121], rhodium [122], palladium [123,124], and platinum [125], these were often preliminary in nature and require further validation $[27,124,126]$. While some metal complexes and metal ions have been shown to possess excellent antimicrobial activity, the question remains whether or not metals offer any significant advantages over purely organic compounds. A common misconception amongst non-inorganic chemists is the notion that metals and their complexes are just generally toxic. To start to address this issue, we analyzed the antimicrobial profile of close to 1000 metal complexes [127]. These compounds were screened by the Community for Open Antimicrobial Drug Discovery (CO-ADD), a global antimicrobial screening platform that screens user-submitted compounds against critical ESKAPE pathogens and two fungal species for free [128-130]. Since 2015, the CO-ADD has profiled almost 300,000 compounds under systematic and 
reproducible conditions. The 906 evaluated metal complexes displayed a hit-rate of $27 \%$ against the tested panel (a hit being defined as having at least one MIC $\leq 16 \mu \mathrm{g} / \mathrm{mL}$ or $10 \mu \mathrm{M}$ ). This contrasts with the substantially lower hit-rate found for purely organic molecules in the CO-ADD database $(1.6 \%)$. Strikingly, this difference was not attributable to increased metal toxicity, as the toxicity rates for both compound classes, as measured by cytotoxicity against HEK293 cells and hemolytic effects against human red blood cells, was found to be similar (64.5\% vs. $64.2 \%)$. Removal of cytotoxic and/or hemolytic compounds still left an overall hit-rate of $9.9 \%$ for metal compounds, compared to $0.87 \%$ for the rest of the CO-ADD database [127]. While this dataset is still rather small, this initial analysis further underscores the potential that metal complexes could bring to the antibiotic drug discovery pipeline.

When it comes to their development as potential drugs, organic molecules do have some advantages compared to metal complexes. Firstly, there is an immense amount of knowledge that has been accumulated over the years on the pharmacological and metabolic behavior of organic compounds. For metal complexes this is still uncharted territory that will require many years of costly and lengthy experiments to explore. The toolkit for the synthesis of organic molecules is vast, with almost any conceivable transformation possible and, more importantly scalable for industrial production. The knowledge of such processes with metal complexes is also rather limited. As stated before, the cost of the metal can be detrimental to the drug development process, particularly in the field of antibiotics, where dosages are high, market competition is harsh, and margins are small. Nevertheless, with costly metals, the compounds could still be developed as last resort-type antibiotics. In this case, the high price could have a beneficial effect as it would discourage indiscriminate use by patients. On the other hand, compounds based on more affordable transition metals do not suffer from this drawback.

As is highlighted in this article, there is clearly much untapped potential in metal complexes for antimicrobial applications. This is evidenced by the increased activity in the field of metal-based antibiotics over the last decade. Despite the head start that organic molecules have in the drug development world, metals do bring some unique advantages to the table.

Metal complexes have access to multiple unique modes of action. They can undergo ligand exchange reactions, release bioactive molecules or be triggered by light irradiation to generate ROS. Alessio and coworkers have previously classified the possible modes of action for anticancer metal compounds and these possibilities are certainly valid for antibiotic applications as well [131]. Some reports have already described the application of metal compounds as catalytic metallodrugs against cancer where the metal complex generates a bioactive compound in situ (or depletes the cells of essential substrates) [132-135]. On top of this, coordination compounds have access to a wide range of 3D geometries. Three-dimensionality of compounds has been associated with higher clinical success in previous work [3,4]. Indeed, a recent study found that metallofragments show excellent potential for fragment-based drug discovery approaches as they cover a higher degree of available three-dimensional chemical space [8].

While some studies, such as the work of Goss et al., found resistance rates comparable to conventional antibiotics with metal complexes, other reports, such as those by Dwyer [69], Sun [67], Fuchs [47], or Sadler [103] found no resistance development even after many rounds of treatment. Since the ROS generated in aPDT treatments has many possible targets, it is difficult for bacteria to develop resistance mechanisms against this therapy. Indeed, no conclusive evidence of resistance against aPDT has been reported to date $[75,77]$. In general, further work is required to probe the capability of bacteria to develop resistance against metal complex-based treatments. But so far the data suggest that metal-compounds are less likely to induce resistance in bacteria.

Another aspect that needs to be included in all future studies of metal complexes are detailed experiments into their stability in water, in the presence of biological media, and human blood. While the synthesized compounds do not necessarily have to be the active drug in the patient (such as is the case for cisplatin), it is imperative that we gather more systematic knowledge about the stability 
and solution behavior of these compounds. Finally, the recent tour de force by the group of Sun illustrates how cutting-edge technology can be used to elucidate the detailed mechanisms of action of metal compounds [136].

Generally, only very limited in vivo efficacy data are available for metal complexes, hindering the further development of potentially promising compounds at this stage. Hopefully future studies will follow the preclinical development path laid out by medicinal organic chemists over the last decades and lead to a better understanding of the in vivo behavior of metal complexes.

It is clear that the golden age of metalloantibiotics is still ahead of us. The number of tested metal-containing compounds is dwarfed by the millions of organic compounds that have been studied to date, highlighting an information gap ripe for filling by the inorganic chemistry community. At the same time, many metals remain unexplored, with the promise of low-hanging fruit for researchers everywhere. There are almost no literature reports for the metals cobalt, nickel, molybdenum, tungsten, and osmium, making these elements interesting starting points for new investigations.

Taken together, the future is bright for this field and the coming decade will likely see many more promising studies on metal-based antibiotics. Optimistically, it is anticipated that a metal-based antibiotic drug candidate will reach clinical trials within the next 10 years.

Funding: The work of the author was supported by the Swiss National Science Foundation with an Early Postdoc.Mobility fellowship (P2ZHP2_177997).

Conflicts of Interest: The author declares no conflict of interest.

\section{References}

1. Available online: https://www.pewtrusts.org/en/research-and-analysis/data-visualizations/2014/antibioticscurrently-in-clinical-development (accessed on 5 February 2020).

2. Holm, R.H.; Kennepohl, P.; Solomon, E.I. Structural and Functional Aspects of Metal Sites in Biology. Chem. Rev. 1996, 96, 2239-2314. [CrossRef]

3. Lovering, F.; Bikker, J.; Humblet, C. Escape from Flatland: Increasing Saturation as an Approach to Improving Clinical Success. J. Med. Chem. 2009, 52, 6752-6756. [CrossRef]

4. Lovering, F. Escape from Flatland 2: Complexity and promiscuity. MedChemComm 2013, 4, 515-519. [CrossRef]

5. Hung, A.W.; Ramek, A.; Wang, Y.; Kaya, T.; Wilson, J.A.; Clemons, P.A.; Young, D.W. Route to three-dimensional fragments using diversity-oriented synthesis. Proc. Natl. Acad. Sci. USA 2011, 108, 6799-6804. [CrossRef]

6. Sauer, W.H.B.; Schwarz, M.K. Molecular Shape Diversity of Combinatorial Libraries: A Prerequisite for Broad Bioactivity. J. Chem. Inf. Comput. Sci. 2003, 43, 987-1003. [CrossRef]

7. Galloway, W.R.J.D.; Isidro-Llobet, A.; Spring, D.R. Diversity-oriented synthesis as a tool for the discovery of novel biologically active small molecules. Nat. Comm. 2010, 1, 80. [CrossRef]

8. Morrison, C.N.; Prosser, K.E.; Stokes, R.W.; Cordes, A.; Metzler-Nolte, N.; Cohen, S.M. Expanding medicinal chemistry into 3D space: Metallofragments as 3D scaffolds for fragment-based drug discovery. Chem. Sci. 2020. [CrossRef]

9. Gasser, G. Metal Complexes and Medicine: A Successful Combination. Chimia 2015, 69, 442-446. [CrossRef]

10. Johnstone, T.C.; Suntharalingam, K.; Lippard, S.J. The Next Generation of Platinum Drugs: Targeted Pt(II) Agents, Nanoparticle Delivery, and Pt(IV) Prodrugs. Chem. Rev. 2016, 116, 3436-3486. [CrossRef]

11. Champion, G.D.; Graham, G.G.; Ziegler, J.B. The gold complexes. Clin. Rheumatol. 1990, 4, 491-534. [CrossRef]

12. Kean, W.F.; Kean, I.R.L.J.I. Clinical pharmacology of gold. Inflammopharmacology 2008, 16, 112-125. [CrossRef]

13. Barnard, P.J.; Berners-Price, S.J. Targeting the mitochondrial cell death pathway with gold compounds. Coord. Chem. Rev. 2007, 251, 1889-1902. [CrossRef]

14. Mirzadeh, N.; Reddy, T.S.; Bhargava, S.K. Advances in diphosphine ligand-containing gold complexes as anticancer agents. Coord. Chem. Rev. 2019, 388, 343-359. [CrossRef] 
15. Harbut, M.B.; Vilchèze, C.; Luo, X.; Hensler, M.E.; Guo, H.; Yang, B.; Chatterjee, A.K.; Nizet, V.; Jacobs, W.R.; Schultz, P.G.; et al. Auranofin exerts broad-spectrum bactericidal activities by targeting thiol-redox homeostasis. Proc. Natl. Acad. Sci. USA 2015, 112, 4453-4458. [CrossRef]

16. Wu, B.; Yang, X.; Yan, M. Synthesis and Structure-Activity Relationship Study of Antimicrobial Auranofin against ESKAPE Pathogens. J. Med. Chem. 2019, 62, 7751-7768. [CrossRef]

17. ClinicalTrials.gov is a Database of Privately and Publicly Funded Clinical Studies Conducted around the World. Available online: www.clinicaltrials.gov (accessed on 5 December 2019).

18. Biot, C.; Nosten, F.; Fraisse, L.; Ter-Minassian, D.; Khalife, J.; Dive, D. The antimalarial ferroquine: From bench to clinic. Parasite 2011, 18, 207-214. [CrossRef]

19. Monro, S.; Colón, K.L.; Yin, H.; Roque, J.; Konda, P.; Gujar, S.; Thummel, R.P.; Lilge, L.; Cameron, C.G.; McFarland, S.A. Transition Metal Complexes and Photodynamic Therapy from a Tumor-Centered Approach: Challenges, Opportunities, and Highlights from the Development of TLD1433. Chem. Rev. 2019, 119, 797-828. [CrossRef]

20. Zeng, L.; Gupta, P.; Chen, Y.; Wang, E.; Ji, L.; Chao, H.; Chen, Z.-S. The development of anticancer ruthenium (ii) complexes: From single molecule compounds to nanomaterials. Chem. Soc. Rev. 2017, 46, 5771-5804. [CrossRef]

21. Kenny, R.G.; Marmion, C.J. Toward Multi-Targeted Platinum and Ruthenium Drugs-A New Paradigm in Cancer Drug Treatment Regimens? Chem. Rev. 2019, 119, 1058-1137. [CrossRef]

22. Korfel, A.; Scheulen, M.E.; Schmoll, H.J.; Gründel, O.; Harstrick, A.; Knoche, M.; Fels, L.M.; Skorzec, M.; Bach, F.; Baumgart, J.; et al. Phase I clinical and pharmacokinetic study of titanocene dichloride in adults with advanced solid tumors. Clin. Cancer Res. 1998, 4, 2701-2708.

23. Hajipour, M.J.; Fromm, K.M.; Akbar Ashkarran, A.; Jimenez de Aberasturi, D.; Larramendi, I.R.D.; Rojo, T.; Serpooshan, V.; Parak, W.J.; Mahmoudi, M. Antibacterial properties of nanoparticles. Trends Biotechnol. 2012, 30, 499-511. [CrossRef]

24. Zheng, K.; Setyawati, M.I.; Leong, D.T.; Xie, J. Antimicrobial silver nanomaterials. Coord. Chem. Rev. 2018, 357, 1-17. [CrossRef]

25. Rajchakit, U.; Sarojini, V. Recent Developments in Antimicrobial-Peptide-Conjugated Gold Nanoparticles. Bioconjugate Chem. 2017, 28, 2673-2686. [CrossRef]

26. Gupta, A.; Mumtaz, S.; Li, C.-H.; Hussain, I.; Rotello, V.M. Combatting antibiotic-resistant bacteria using nanomaterials. Chem. Soc. Rev. 2019, 48, 415-427. [CrossRef]

27. Sierra, M.A.; Casarrubios, L.; de la torre, M.C. Bio-Organometallic Derivatives of Antibacterial Drugs. Chem. Eur. J. 2019, 25, 7232-7242. [CrossRef]

28. Hill, W.R.; Pillsbury, D.M. Argyria: The Pharmacology of Silver; Williams \& Wilkins: Baltimore, MD, USA, 1939.

29. Alexander, J.W. History of the Medical Use of Silver. Surg. Infect. 2009, 10, 289-292. [CrossRef]

30. Mjos, K.D.; Orvig, C. Metallodrugs in Medicinal Inorganic Chemistry. Chem. Rev. 2014, 114, 4540-4563. [CrossRef]

31. Aziz, Z.; Abu, S.F.; Chong, N.J. A systematic review of silver-containing dressings and topical silver agents (used with dressings) for burn wounds. Burns 2012, 38, 307-318. [CrossRef]

32. Wattanaploy, S.; Chinaroonchai, K.; Namviriyachote, N.; Muangman, P. Randomized Controlled Trial of Polyhexanide/Betaine Gel Versus Silver Sulfadiazine for Partial-Thickness Burn Treatment. Int. J. Lower Extrem. Wounds 2017, 16, 45-50. [CrossRef]

33. Rashaan, Z.M.; Krijnen, P.; Kwa, K.A.A.; van der Vlies, C.H.; Schipper, I.B.; Breederveld, R.S. Flaminal ${ }^{\circledR}$ versus Flamazine ${ }^{\circledR}$ in the treatment of partial thickness burns: A randomized controlled trial on clinical effectiveness and scar quality (FLAM study). Wound Repair Regen. 2019, 27, 257-267. [CrossRef]

34. Maciel, A.B.D.S.; Ortiz, J.F.; Siqueira, B.S.; Zanette, G.F. Tissue healing efficacy in burn patients treated with $1 \%$ silver sulfadiazine versus other treatments: A systematic review and meta-analysis of randomized controlled trials. An. Bras. Dermatol. 2019, 94, 204-210. [CrossRef]

35. Kascatan-Nebioglu, A.; Panzner, M.J.; Tessier, C.A.; Cannon, C.L.; Youngs, W.J. N-Heterocyclic carbene-silver complexes: A new class of antibiotics. Coord. Chem. Rev. 2007, 251, 884-895. [CrossRef]

36. Medici, S.; Peana, M.; Crisponi, G.; Nurchi, V.M.; Lachowicz, J.I.; Remelli, M.; Zoroddu, M.A. Silver coordination compounds: A new horizon in medicine. Coord. Chem. Rev. 2016, 327, 349-359. [CrossRef]

37. Johnson, N.A.; Southerland, M.R.; Youngs, W.J. Recent Developments in the Medicinal Applications of Silver-NHC Complexes and Imidazolium Salts. Molecules 2017, 22, 1263. [CrossRef] 
38. Wang, H.; Yan, A.; Liu, Z.; Yang, X.; Xu, Z.; Wang, Y.; Wang, R.; Koohi-Moghadam, M.; Hu, L.; Xia, W.; et al. Deciphering molecular mechanism of silver by integrated omic approaches enables enhancing its antimicrobial efficacy in E. coli. PLoS Biol. 2019, 17, e3000292. [CrossRef]

39. Wang, H.; Wang, M.; Yang, X.; Xu, X.; Hao, Q.; Yan, A.; Hu, M.; Lobinski, R.; Li, H.; Sun, H. Antimicrobial silver targets glyceraldehyde-3-phosphate dehydrogenase in glycolysis of E. coli. Chem. Sci. 2019, 10, 7193-7199. [CrossRef]

40. Koch, R. Über bakteriologische Forschung. Dtsch. Med. Wochenschr. 1890, 16, 756-757.

41. Glišić, B.Đ.; Djuran, M.I. Gold complexes as antimicrobial agents: An overview of different biological activities in relation to the oxidation state of the gold ion and the ligand structure. Dalton Trans. 2014, 43, 5950-5969. [CrossRef]

42. Mora, M.; Gimeno, M.C.; Visbal, R. Recent advances in gold-NHC complexes with biological properties. Chem. Soc. Rev. 2019, 48, 447-462. [CrossRef]

43. Dominelli, B.; Correia, J.D.G.; Kühn, F.E. Medicinal Applications of Gold(I/III)-Based Complexes Bearing N-Heterocyclic Carbene and Phosphine Ligands. J. Organomet. Chem. 2018, 866, 153-164. [CrossRef]

44. Marzo, T.; Cirri, D.; Pollini, S.; Prato, M.; Fallani, S.; Cassetta, M.I.; Novelli, A.; Rossolini, G.M.; Messori, L. Auranofin and its Analogues Show Potent Antimicrobial Activity against Multidrug-Resistant Pathogens: Structure-Activity Relationships. ChemMedChem 2018, 13, 2448-2454. [CrossRef]

45. Thangamani, S.; Mohammad, H.; Abushahba, M.F.N.; Sobreira, T.J.P.; Hedrick, V.E.; Paul, L.N.; Seleem, M.N. Antibacterial activity and mechanism of action of auranofin against multi-drug resistant bacterial pathogens. Sci. Rep. 2016, 6, 22571. [CrossRef]

46. Blodgett, R.; Pietrusko, R. Long-term efficacy and safety of auranofin: A review of clinical experience. Scand. J. Rhenmatol. Suppl. 1986, 63, 67-78.

47. Tharmalingam, N.; Ribeiro, N.Q.; Silva, D.L.D.; Naik, M.T.; Cruz, L.I.; Kim, W.; Shen, S.; Santos, J.D.d.; Ezikovich, K.; D'Agata, E.M.; et al. Auranofin is an effective agent against clinical isolates of Staphylococcus aureus. Future Med. Chem. 2019, 11, 1417-1425. [CrossRef]

48. She, P.; Zhou, L.; Li, S.; Liu, Y.; Xu, L.; Chen, L.; Luo, Z.; Wu, Y. Synergistic Microbicidal Effect of Auranofin and Antibiotics Against Planktonic and Biofilm-Encased S. aureus and E. faecalis. Front. Microbiol. 2019, 10. [CrossRef]

49. Epstein, T.D.; Wu, B.; Moulton, K.D.; Yan, M.; Dube, D.H. Sugar-Modified Analogs of Auranofin Are Potent Inhibitors of the Gastric Pathogen Helicobacter pylori. ACS Infect. Dis. 2019, 5, 1682-1687. [CrossRef]

50. Bonchi, C.; Imperi, F.; Minandri, F.; Visca, P.; Frangipani, E. Repurposing of gallium-based drugs for antibacterial therapy. BioFactors 2014, 40, 303-312. [CrossRef]

51. Choi, S.-R.; Britigan, B.E.; Narayanasamy, P. Dual Inhibition of Klebsiella pneumoniae and Pseudomonas aeruginosa Iron Metabolism Using Gallium Porphyrin and Gallium Nitrate. ACS Infect. Dis. 2019, 5, 1559-1569. [CrossRef]

52. Ooi, M.L.; Richter, K.; Drilling, A.J.; Thomas, N.; Prestidge, C.A.; James, C.; Moratti, S.; Vreugde, S.; Psaltis, A.J.; Wormald, P.-J. Safety and Efficacy of Topical Chitogel- Deferiprone-Gallium Protoporphyrin in Sheep Model. Front. Cell. Infect. Microbiol. 2018, 9. [CrossRef]

53. Banin, E.; Vasil, M.L.; Greenberg, E.P. Iron and Pseudomonas aeruginosa biofilm formation. Proc. Natl. Acad. Sci. USA 2005, 102, 11076-11081. [CrossRef]

54. Banin, E.; Lozinski, A.; Brady, K.M.; Berenshtein, E.; Butterfield, P.W.; Moshe, M.; Chevion, M.; Greenberg, E.P.; Banin, E. The potential of desferrioxamine-gallium as an anti-Pseudomonas therapeutic agent. Proc. Natl. Acad. Sci. USA 2008, 105, 16761-16766. [CrossRef] [PubMed]

55. Antunes, L.C.S.; Imperi, F.; Minandri, F.; Visca, P. In vitro and In vivo Antimicrobial Activities of Gallium Nitrate against Multidrug-Resistant Acinetobacter baumannii. Antimicrob. Agents Chemother. 2012, 56, 5961-5970. [CrossRef] [PubMed]

56. Hijazi, S.; Visaggio, D.; Pirolo, M.; Frangipani, E.; Bernstein, L.; Visca, P. Antimicrobial Activity of Gallium Compounds on ESKAPE Pathogens. Front. Cell. Infect. Microbiol. 2018, 8. [CrossRef]

57. Goss, C.H.; Kaneko, Y.; Khuu, L.; Anderson, G.D.; Ravishankar, S.; Aitken, M.L.; Lechtzin, N.; Zhou, G.; Czyz, D.M.; McLean, K.; et al. Gallium disrupts bacterial iron metabolism and has therapeutic effects in mice and humans with lung infections. Sci. Transl. Med. 2018, 10, eaat7520. [CrossRef] [PubMed]

58. Available online: https://www.cff.org/Trials/pipeline (accessed on 17 December 2019). 
59. Pandey, A.; Savino, C.; Ahn, S.H.; Yang, Z.; Van Lanen, S.G.; Boros, E. Theranostic Gallium Siderophore Ciprofloxacin Conjugate with Broad Spectrum Antibiotic Potency. J. Med. Chem. 2019, 62, 9947-9960. [CrossRef]

60. Chitambar, C.R. Gallium and its competing roles with iron in biological systems. Biochim. Biophys. Acta Mol. Cell Res. 2016, 1863, 2044-2053. [CrossRef]

61. Wang, Y.; Han, B.; Xie, Y.; Wang, H.; Wang, R.; Xia, W.; Li, H.; Sun, H. Combination of gallium(iii) with acetate for combating antibiotic resistant Pseudomonas aeruginosa. Chem. Sci. 2019, 10, 6099-6106. [CrossRef]

62. Sun, H. Biological Chemistry of Arsenic, Antimony and Bismuth; Wiley: Chichester, UK, 2011.

63. Fock, K.M.; Graham, D.Y.; Malfertheiner, P. Helicobacter pylori research: Historical insights and future directions. Nat. Rev. Gastroenterol. Hepatol. 2013, 10, 495-500. [CrossRef]

64. Li, H.; Wang, R.; Sun, H. Systems Approaches for Unveiling the Mechanism of Action of Bismuth Drugs: New Medicinal Applications beyond Helicobacter Pylori Infection. Acc. Chem. Res. 2019, 52, $216-227$. [CrossRef]

65. Li, H.; Sun, H. Recent advances in bioinorganic chemistry of bismuth. Curr. Opin. Chem. Biol. 2012, 16, 74-83. [CrossRef]

66. Hong, Y.; Lai, Y.-T.; Chan, G.C.-F.; Sun, H. Glutathione and multidrug resistance protein transporter mediate a self-propelled disposal of bismuth in human cells. Proc. Natl. Acad. Sci. USA 2015, 112, 3211-3216. [CrossRef] [PubMed]

67. Wang, Y.; Hu, L.; Xu, F.; Quan, Q.; Lai, Y.-T.; Xia, W.; Yang, Y.; Chang, Y.-Y.; Yang, X.; Chai, Z.; et al. Integrative approach for the analysis of the proteome-wide response to bismuth drugs in Helicobacter pylori. Chem. Sci. 2017, 8, 4626-4633. [CrossRef] [PubMed]

68. Wang, R.; Lai, T.-P.; Gao, P.; Zhang, H.; Ho, P.-L.; Woo, P.C.-Y.; Ma, G.; Kao, R.Y.-T.; Li, H.; Sun, H. Bismuth antimicrobial drugs serve as broad-spectrum metallo- $\beta$-lactamase inhibitors. Nat. Comm. 2018, 9, 439. [CrossRef] [PubMed]

69. Dwyer, F.P.; Gyarfas, E.C.; Rogers, W.P.; Koch, J.H. Biological Activity of Complex Ions. Nature 1952, 170, 190-191. [CrossRef]

70. Dwyer, F.; Reid, I.; Shulman, A.; Laycock, G.M.; Dixson, S. The biological actions of 1,10-phenanthroline and 2,2'-bipyridine hydrochlorides, quaternary salts and metal chelates and related compounds. Aust. J. Exp. Biol. Med. 1969, 47, 203-218. [CrossRef]

71. Brandt, W.W.; Dwyer, F.P.; Gyarfas, E.D. Chelate Complexes of 1,10-Phenanthroline and Related Compounds. Chem. Rev. 1954, 54, 959-1017. [CrossRef]

72. Li, F.; Collins, J.G.; Keene, F.R. Ruthenium complexes as antimicrobial agents. Chem. Soc. Rev. 2015, 44, 2529-2542. [CrossRef]

73. Bolhuis, A.; Hand, L.; Marshall, J.E.; Richards, A.D.; Rodger, A.; Aldrich-Wright, J. Antimicrobial activity of ruthenium-based intercalators. Eur. J. Pharm. Sci. 2011, 42, 313-317. [CrossRef]

74. Heinemann, F.; Karges, J.; Gasser, G. Critical Overview of the Use of Ru (II) Polypyridyl Complexes as Photosensitizers in One-Photon and Two-Photon Photodynamic Therapy. Acc. Chem. Res. 2017, 50, 2727-2736. [CrossRef]

75. Cieplik, F.; Deng, D.; Crielaard, W.; Buchalla, W.; Hellwig, E.; Al-Ahmad, A.; Maisch, T. Antimicrobial photodynamic therapy - what we know and what we don't. Crit. Rev. Microbiol. 2018, 44, 571-589. [CrossRef]

76. Wainwright, M.; Maisch, T.; Nonell, S.; Plaetzer, K.; Almeida, A.; Tegos, G.P.; Hamblin, M.R. Photoantimicrobials-Are we afraid of the light? Lancet Infect. Dis. 2017, 17, e49-e55. [CrossRef]

77. Kashef, N.; Hamblin, M.R. Can microbial cells develop resistance to oxidative stress in antimicrobial photodynamic inactivation? Drug Resist. Updat. 2017, 31, 31-42. [CrossRef]

78. Donnelly, R.F.; Fletcher, N.C.; McCague, P.J.; Donnelly, J.; McCarron, P.A.; Tunney, M.M. Design, Synthesis and Photodynamic Antimicrobial Activity of Ruthenium Trischelate Diimine Complexes. Lett. Drug Des. Discov. 2007, 4, 175-179. [CrossRef]

79. Frei, A.; Rubbiani, R.; Tubafard, S.; Blacque, O.; Anstaett, P.; Felgenträger, A.; Maisch, T.; Spiccia, L.; Gasser, G. Synthesis, Characterization, and Biological Evaluation of New Ru(II) Polypyridyl Photosensitizers for Photodynamic Therapy. J. Med. Chem. 2014, 57, 7280-7292. [CrossRef] [PubMed] 
80. Le Gall, T.; Lemercier, G.; Chevreux, S.; Tücking, K.-S.; Ravel, J.; Thétiot, F.; Jonas, U.; Schönherr, H.; Montier, T. Ruthenium (II) Polypyridyl Complexes as Photosensitizers for Antibacterial Photodynamic Therapy: A Structure-Activity Study on Clinical Bacterial Strains. ChemMedChem 2018, 13, 2229-2239. [CrossRef]

81. Feng, Y.; Sun, W.-Z.; Wang, X.-S.; Zhou, Q.-X. Selective Photoinactivation of Methicillin-Resistant Staphylococcus aureus by Highly Positively Charged RuII Complexes. Chem. Eur. J. 2019, 25, 13879-13884. [CrossRef] [PubMed]

82. Smith, N.A.; Zhang, P.; Greenough, S.E.; Horbury, M.D.; Clarkson, G.J.; McFeely, D.; Habtemariam, A.; Salassa, L.; Stavros, V.G.; Dowson, C.G.; et al. Combatting AMR: Photoactivatable ruthenium(ii)-isoniazid complex exhibits rapid selective antimycobacterial activity. Chem. Sci. 2017, 8, 395-404. [CrossRef] [PubMed]

83. Lewandowski, E.M.; Skiba, J.; Torelli, N.J.; Rajnisz, A.; Solecka, J.; Kowalski, K.; Chen, Y. Antibacterial properties and atomic resolution X-ray complex crystal structure of a ruthenocene conjugated $\beta$-lactam antibiotic. Chem. Commun. 2015, 51, 6186-6189. [CrossRef] [PubMed]

84. Skiba, J.; Rajnisz, A.; de Oliveira, K.N.; Ott, I.; Solecka, J.; Kowalski, K. Ferrocenyl bioconjugates of ampicillin and 6-aminopenicillinic acid - Synthesis, electrochemistry and biological activity. Eur. J. Med. Chem. 2012, 57, 234-239. [CrossRef]

85. Li, F.; Mulyana, Y.; Feterl, M.; Warner, J.M.; Collins, J.G.; Keene, F.R. The antimicrobial activity of inert oligonuclear polypyridylruthenium(ii) complexes against pathogenic bacteria, including MRSA. Dalton Trans. 2011, 40, 5032-5038. [CrossRef]

86. Li, F.; Feterl, M.; Mulyana, Y.; Warner, J.M.; Collins, J.G.; Keene, F.R. In vitro susceptibility and cellular uptake for a new class of antimicrobial agents: Dinuclear ruthenium (II) complexes. J. Antimicrob. Chemother. 2012, 67, 2686-2695. [CrossRef] [PubMed]

87. Li, F.; Harry, E.J.; Bottomley, A.L.; Edstein, M.D.; Birrell, G.W.; Woodward, C.E.; Keene, F.R.; Collins, J.G. Dinuclear ruthenium (ii) antimicrobial agents that selectively target polysomes in vivo. Chem. Sci. 2014, 5, 685-693. [CrossRef]

88. Weber, D.K.; Sani, M.-A.; Downton, M.T.; Separovic, F.; Keene, F.R.; Collins, J.G. Membrane Insertion of a Dinuclear Polypyridylruthenium(II) Complex Revealed by Solid-State NMR and Molecular Dynamics Simulation: Implications for Selective Antibacterial Activity. J. Am. Chem. Soc. 2016, 138, 15267-15277. [CrossRef]

89. Li, X.; Gorle, A.K.; Ainsworth, T.D.; Heimann, K.; Woodward, C.E.; Grant Collins, J.; Richard Keene, F. RNA and DNA binding of inert oligonuclear ruthenium (ii) complexes in live eukaryotic cells. Dalton Trans. 2015, 44, 3594-3603. [CrossRef]

90. Gorle, A.K.; Feterl, M.; Warner, J.M.; Wallace, L.; Keene, F.R.; Collins, J.G. Tri- and tetra-nuclear polypyridyl ruthenium (ii) complexes as antimicrobial agents. Dalton Trans. 2014, 43, 16713-16725. [CrossRef]

91. Pandrala, M.; Li, F.; Feterl, M.; Mulyana, Y.; Warner, J.M.; Wallace, L.; Keene, F.R.; Collins, J.G. Chlorido-containing ruthenium (ii) and iridium (iii) complexes as antimicrobial agents. Dalton Trans. 2013, 42, 4686-4694. [CrossRef] [PubMed]

92. Smitten, K.L.; Southam, H.M.; de la Serna, J.B.; Gill, M.R.; Jarman, P.J.; Smythe, C.G.W.; Poole, R.K.; Thomas, J.A. Using Nanoscopy To Probe the Biological Activity of Antimicrobial Leads That Display Potent Activity against Pathogenic, Multidrug Resistant, Gram-Negative Bacteria. ACS Nano 2019, 13, 5133-5146. [CrossRef] [PubMed]

93. Gross, M.; Cramton, S.E.; Götz, F.; Peschel, A. Key Role of Teichoic Acid Net Charge in Staphylococcus aureus Colonization of Artificial Surfaces. Infect. Immun. 2001, 69, 3423-3426. [CrossRef] [PubMed]

94. Smitten, K.L.; Fairbanks, S.D.; Robertson, C.C.; Bernardino de la Serna, J.; Foster, S.J.; Thomas, J.A. Ruthenium based antimicrobial theranostics-Using nanoscopy to identify therapeutic targets and resistance mechanisms in Staphylococcus aureus. Chem. Sci. 2019. [CrossRef]

95. Pandrala, M.; Li, F.; Wallace, L.; Steel, P.J.; Moore II, B.; Autschbach, J.; Collins, J.G.; Keene, F.R. Iridium (iii) Complexes Containing 1,10-Phenanthroline and Derivatives: Synthetic, Stereochemical, and Structural Studies, and their Antimicrobial Activity. Aust. J. Chem. 2013, 66, 1065-1073. [CrossRef]

96. Lu, L.; Liu, L.-J.; Chao, W.-C.; Zhong, H.-J.; Wang, M.; Chen, X.-P.; Lu, J.-J.; Li, R.-N.; Ma, D.-L.; Leung, C.-H. Identification of an iridium (III) complex with anti-bacterial and anti-cancer activity. Sci. Rep. 2015, 5, 14544. [CrossRef] [PubMed] 
97. Jain, N.; Alam, P.; Laskar, I.R.; Panwar, J. Aggregation induced phosphorescence active iridium (iii) complexes for integrated sensing and inhibition of bacterial growth in aqueous solution. RSC Adv. 2015, 5, 61983-61988. [CrossRef]

98. Sauvageot, E.; Elie, M.; Gaillard, S.; Daniellou, R.; Fechter, P.; Schalk, I.J.; Gasser, V.; Renaud, J.L.; Mislin, G.L.A. Antipseudomonal activity enhancement of luminescent iridium(iii) dipyridylamine complexes under visible blue light. Metallomics 2017, 9, 1820-1827. [CrossRef]

99. Huang, H.; Banerjee, S.; Sadler, P.J. Recent Advances in the Design of Targeted Iridium(III) Photosensitizers for Photodynamic Therapy. ChemBioChem 2018, 19, 1574-1589. [CrossRef] [PubMed]

100. Karpin, G.W.; Merola, J.S.; Falkinham, J.O. Transition Metal- $\alpha$-Amino Acid Complexes with Antibiotic Activity against Mycobacterium spp. Antimicrob. Agents Chemother. 2013, 57, 3434-3436. [CrossRef] [PubMed]

101. Karpin, G.W.; Morris, D.M.; Ngo, M.T.; Merola, J.S.; Falkinham, J.O. Transition metal diamine complexes with antimicrobial activity against Staphylococcus aureus and methicillin-resistant S. aureus (MRSA). MedChemComm 2015, 6, 1471-1478. [CrossRef]

102. DuChane, C.M.; Karpin, G.W.; Ehrich, M.; Falkinham, J.O.; Merola, J.S. Iridium piano stool complexes with activity against $\mathrm{S}$. aureus and MRSA: It is past time to truly think outside of the box. MedChemComm 2019, 10, 1391-1398. [CrossRef]

103. Chen, F.; Moat, J.; McFeely, D.; Clarkson, G.; Hands-Portman, I.J.; Furner-Pardoe, J.P.; Harrison, F.; Dowson, C.G.; Sadler, P.J. Biguanide Iridium (III) Complexes with Potent Antimicrobial Activity. J. Med. Chem. 2018, 61, 7330-7344. [CrossRef]

104. Metalsdaily. Available online: https://www.metalsdaily.com (accessed on 5 December 2019).

105. Konkankit, C.C.; Marker, S.C.; Knopf, K.M.; Wilson, J.J. Anticancer activity of complexes of the third row transition metals, rhenium, osmium, and iridium. Dalton Trans. 2018, 47, 9934-9974. [CrossRef]

106. Bauer, E.B.; Haase, A.A.; Reich, R.M.; Crans, D.C.; Kühn, F.E. Organometallic and coordination rhenium compounds and their potential in cancer therapy. Coord. Chem. Rev. 2019, 393, 79-117. [CrossRef]

107. Patra, M.; Gasser, G.; Bobukhov, D.; Merz, K.; Shtemenko, A.V.; Metzler-Nolte, N. Sequential insertion of three different organometallics into a versatile building block containing a PNA backbone. Dalton Trans. 2010, 39, 5617-5619. [CrossRef] [PubMed]

108. Patra, M.; Wenzel, M.; Prochnow, P.; Pierroz, V.; Gasser, G.; Bandow, J.E.; Metzler-Nolte, N. An organometallic structure-activity relationship study reveals the essential role of a $\operatorname{Re}(\mathrm{CO}) 3$ moiety in the activity against gram-positive pathogens including MRSA. Chem. Sci. 2015, 6, 214-224. [CrossRef] [PubMed]

109. Wenzel, M.; Patra, M.; Senges, C.H.R.; Ott, I.; Stepanek, J.J.; Pinto, A.; Prochnow, P.; Vuong, C.; Langklotz, S.; Metzler-Nolte, N.; et al. Analysis of the Mechanism of Action of Potent Antibacterial Hetero-tri-organometallic Compounds: A Structurally New Class of Antibiotics. ACS Chem. Biol. 2013, 8, 1442-1450. [CrossRef] [PubMed]

110. Frei, A.; Amado, M.; Cooper, M.A.; Blaskovich, M.A.T. Light-activated Rhenium Complexes with Dual Mode of Action against Bacteria. Chem. Eur. J. 2019. [CrossRef]

111. Siegmund, D.; Lorenz, N.; Gothe, Y.; Spies, C.; Geissler, B.; Prochnow, P.; Nuernberger, P.; Bandow, J.E.; Metzler-Nolte, N. Benzannulated Re (i)-NHC complexes: Synthesis, photophysical properties and antimicrobial activity. Dalton Trans. 2017, 46, 15269-15279. [CrossRef]

112. Metzler-Nolte, N.; Siegmund, D.; Bandow, J.E.; Schäkermann, S. EF-Tu-binding antibiotics containing benzimidazolylidene NHC-carbene rhenium complexes with chelating diimine ligands. Patent WO2019007664, 2019.

113. Feng, Q.L.; Wu, J.; Chen, G.Q.; Cui, F.Z.; Kim, T.N.; Kim, J.O. A mechanistic study of the antibacterial effect of silver ions on Escherichia coli and Staphylococcus aureus. J. Biomed. Mater. Res. 2000, 52, 662-668. [CrossRef]

114. Hijazi, S.; Visca, P.; Frangipani, E. Gallium-Protoporphyrin IX Inhibits Pseudomonas aeruginosa Growth by Targeting Cytochromes. Front. Cell. Infect. Microbiol. 2017, 7. [CrossRef]

115. Patra, M.; Gasser, G.; Pinto, A.; Merz, K.; Ott, I.; Bandow, J.E.; Metzler-Nolte, N. Synthesis and Biological Evaluation of Chromium Bioorganometallics Based on the Antibiotic Platensimycin Lead Structure. ChemMedChem 2009, 4, 1930-1938. [CrossRef]

116. Patra, M.; Gasser, G.; Wenzel, M.; Merz, K.; Bandow, J.E.; Metzler-Nolte, N. Synthesis and Biological Evaluation of Ferrocene-Containing Bioorganometallics Inspired by the Antibiotic Platensimycin Lead Structure. Organometallics 2010, 29, 4312-4319. [CrossRef] 
117. Zobi, F. CO and CO-releasing molecules in medicinal chemistry. Future Med. Chem. 2013, 5, 175-188. [CrossRef]

118. Ward, J.S.; Lynam, J.M.; Moir, J.; Fairlamb, I.J.S. Visible-Light-Induced CO Release from a Therapeutically Viable Tryptophan-Derived Manganese (I) Carbonyl (TryptoCORM) Exhibiting Potent Inhibition against E. coli. Chem. Eur. J. 2014, 20, 15061-15068. [CrossRef] [PubMed]

119. Ward, J.S.; Morgan, R.; Lynam, J.M.; Fairlamb, I.J.S.; Moir, J.W.B. Toxicity of tryptophan manganese (i) carbonyl (Trypto-CORM), against Neisseria gonorrhoeae. MedChem Comm 2017, 8, 346-352. [CrossRef] [PubMed]

120. Simpson, P.V.; Nagel, C.; Bruhn, H.; Schatzschneider, U. Antibacterial and Antiparasitic Activity of Manganese (I) Tricarbonyl Complexes with Ketoconazole, Miconazole, and Clotrimazole Ligands. Organometallics 2015, 34, 3809-3815. [CrossRef]

121. Low, M.L.; Maigre, L.; Dorlet, P.; Guillot, R.; Pagès, J.-M.; Crouse, K.A.; Policar, C.; Delsuc, N. Conjugation of a New Series of Dithiocarbazate Schiff Base Copper(II) Complexes with Vectors Selected to Enhance Antibacterial Activity. Bioconjugate Chem. 2014, 25, 2269-2284. [CrossRef]

122. Yang, X.-Y.; Xu, J.-Y.; Meng, M.; Li, N.; Liu, C.-Y.; He, Q.-Y. Dirhodium (II) complex interferes with iron-transport system to exert antibacterial action against Streptococcus pneumoniae. J. Proteom. 2019, 194, 160-167. [CrossRef]

123. Kalaivani, P.; Prabhakaran, R.; Ramachandran, E.; Dallemer, F.; Paramaguru, G.; Renganathan, R.; Poornima, P.; Vijaya Padma, V.; Natarajan, K. Influence of terminal substitution on structural, DNA, Protein binding, anticancer and antibacterial activities of palladium (ii) complexes containing 3-methoxy salicylaldehyde-4(N) substituted thiosemicarbazones. Dalton Trans. 2012, 41, 2486-2499. [CrossRef]

124. Kalaivani, P.; Prabhakaran, R.; Dallemer, F.; Poornima, P.; Vaishnavi, E.; Ramachandran, E.; Padma, V.V.; Renganathan, R.; Natarajan, K. DNA, protein binding, cytotoxicity, cellular uptake and antibacterial activities of new palladium (ii) complexes of thiosemicarbazone ligands: Effects of substitution on biological activity. Metallomics 2012, 4, 101-113. [CrossRef]

125. Johnstone, T.C.; Alexander, S.M.; Lin, W.; Lippard, S.J. Effects of Monofunctional Platinum Agents on Bacterial Growth: A Retrospective Study. J. Am. Chem. Soc. 2014, 136, 116-118. [CrossRef]

126. Patra, M.; Gasser, G.; Metzler-Nolte, N. Small organometallic compounds as antibacterial agents. Dalton Trans. 2012, 41, 6350-6358. [CrossRef]

127. Frei, A.; Zuegg, J.; Elliott, A.G.; Baker, M.V.; Braese, S.; Brown, C.; Chen, F.; Dowson, C.G.; Dujardin, G.; Jung, N.; et al. Metal Complexes as a Promising Source for New Antibiotics. Chem. Sci. 2020. [CrossRef]

128. Hansford, K.A.; Blaskovich, M.A.; Cooper, M.A. Chemical philanthropy: A path forward for antibiotic discovery? Future Med. Chem. 2016, 8, 925-929. [CrossRef] [PubMed]

129. Cooper, M.A. A community-based approach to new antibiotic discovery. Nat. Rev. Drug Discov. 2015, 14, 587-588. [CrossRef] [PubMed]

130. Blaskovich, M.A.T.; Zuegg, J.; Elliott, A.G.; Cooper, M.A. Helping Chemists Discover New Antibiotics. ACS Infect. Dis. 2015, 1, 285-287. [CrossRef] [PubMed]

131. Gianferrara, T.; Bratsos, I.; Alessio, E. A categorization of metal anticancer compounds based on their mode of action. Dalton Trans. 2009, 7588-7598. [CrossRef] [PubMed]

132. Dougan, S.J.; Habtemariam, A.; McHale, S.E.; Parsons, S.; Sadler, P.J. Catalytic organometallic anticancer complexes. Proc. Natl. Acad. Sci. USA 2008, 105, 11628-11633. [CrossRef] [PubMed]

133. Coverdale, J.P.C.; Romero-Canelón, I.; Sanchez-Cano, C.; Clarkson, G.J.; Habtemariam, A.; Wills, M.; Sadler, P.J. Asymmetric transfer hydrogenation by synthetic catalysts in cancer cells. Nat. Chem. 2018, 10, 347. [CrossRef] [PubMed]

134. Huang, H.; Banerjee, S.; Qiu, K.; Zhang, P.; Blacque, O.; Malcomson, T.; Paterson, M.J.; Clarkson, G.J.; Staniforth, M.; Stavros, V.G.; et al. Targeted photoredox catalysis in cancer cells. Nature Chem. 2019. [CrossRef] 
135. Soldevila-Barreda, J.J.; Romero-Canelón, I.; Habtemariam, A.; Sadler, P.J. Transfer hydrogenation catalysis in cells as a new approach to anticancer drug design. Nat. Commun. 2015, 6, 6582. [CrossRef]

136. Wang, Y.; Li, H.; Sun, H. Metalloproteomics for Unveiling the Mechanism of Action of Metallodrugs. Inorg. Chem. 2019, 58, 13673-13685. [CrossRef]

(C) 2020 by the author. Licensee MDPI, Basel, Switzerland. This article is an open access article distributed under the terms and conditions of the Creative Commons Attribution (CC BY) license (http://creativecommons.org/licenses/by/4.0/). 